\title{
Rotaxane-Based Transition Metal Complexes: Effect of the Mechani- cal Bond on Structure and Electronic Properties
}

\author{
Martina Cirulli, ${ }^{1+}$ Amanpreet Kaur, ${ }^{2 !}$ James E. M. Lewis, ${ }^{2,3}$ Zhihui Zhang, ${ }^{2}$ Jonathan A. Kitchen, ${ }^{4}$ \\ Stephen M. Goldup ${ }^{2, *}$ and Maxie M. Roessler ${ }^{1,{ }^{*}}$ \\ ${ }^{1}$ School of Biological and Chemical Sciences and Materials Research Institute, Queen Mary University of London, \\ Mile End Road, London E1 4NS, U.K. \\ ${ }^{2}$ Chemistry, University of Southampton, Highfield, Southampton, SO17 1BJ, UK. \\ ${ }^{3}$ Department of Chemistry, Imperial College London, Molecular Sciences Research Hub, 8o Wood Lane, W12 oBZ, \\ U.K. \\ ${ }^{4}$ Chemistry, Institute of Natural and Mathematical Sciences, Massey University, Auckland, New Zealand
}

\begin{abstract}
Early work by Sauvage revealed that mechanical bonding alters the stability and redox properties of their original catenane metal complexes. However, despite the importance of controlling metal ion properties for a range of applications, these effects have received relatively little attention since. Here we present a series of tri-, tetra- and pentadentate rotaxane-based ligands, a detailed study of their metal binding behavior and, where possible, compare their redox and electronic properties with their non-interlocked counterparts. The rotaxane ligands form complexes with most of the metal ions investigated and x-ray diffraction revealed that in some cases the mechanical bond enforces unusual coordination numbers and distorted arrangements as a result of the exclusion of exogenous ligands driven by the sterically crowded binding sites. In contrast, only the non-interlocked equivalent of the pentadentate rotaxane $\mathrm{Cu}^{\mathrm{II}}$ complex could be formed selectively, and this exhibited compromised redox stability compared to its interlocked counterpart. Frozen-solution EPR data demonstrate the formation of an interesting biomimetic state for the tetradentate $\mathrm{Cu}^{\mathrm{II}}$ rotaxane, as well as the formation of stable $\mathrm{Ni}^{\mathrm{I}}$ species and the unusual coexistence of high- and low-spin $\mathrm{Co}^{\mathrm{II}}$ in the pentadentate framework. Our results demonstrate that readily available mechanically chelating rotaxanes give rise to complexes the non-interlocked equivalent of which are inaccessible, and that the mechanical bond augments the redox behavior of the bound metal ion in a manner analogous to the carefully-tuned amino acid framework in metalloproteins.
\end{abstract}

\section{- INTRODUCTION}

Controlling coordination number and geometry is a central problem in the chemistry of transition metal ions that touches on a range of applications including catalysis, photochemistry and medicinal inorganic chemistry. A number of general chelating ligand platforms have been developed to address this challenge including pincer, ${ }^{1}$ scorpionate $^{2}$ macrocyclic ${ }^{3}$ ligands, all of which present multiple covalently linked donor atoms in a specific geometry to the metal ion. ${ }^{4}$ In this, synthetic chemists are taking inspiration from nature's metalloenzymes in which the active site presents donor atoms to the metal ion in a highly preorganised fashion in order to achieve what has been termed an "entatic state" 5,6 whose properties are finely tuned to match their biological function.

Since 1983, when Sauvage and co-workers revolutionized the synthesis of mechanically interlocked molecules by introducing the passive metal template approach, ${ }^{7}$ a large number of "mechanically chelating" ligands, molecules in which metal-ligand interactions bridge the covalent subcomponents of an interlocked molecule, have been reported. ${ }^{8,9}$ These systems are reminiscent of the cavitands $^{10}$ and cryptands ${ }^{11}$ in that the space between the components creates a crowded environment into which the donor atoms are presented. Indeed, one of the first observations made by Sauvage was that $\mathrm{Cu}^{\mathrm{I}}$ complexes of their original "homoleptic" ${ }_{12}$ bis-phenanthroline catenane ligand were significantly stabilized to nucleophilic demetallation compared with complexes formed from similar non-interlocked ligands and this was dubbed the "catenand" effect by direct analogy with the properties of cryptands. ${ }^{13}$ Furthermore, the restricted environment of the mechanical bond altered the redox properties of bound metal ions, kinetically stabilizing low oxidation states ${ }^{13 \mathrm{C}}$ and preventing access to higher oxidation states. ${ }^{13 \mathrm{~d}}$

However, despite the central role that metal ions play in a variety of areas and the potential for the mechanical bond to be used to augment their structure and thus electronic and other properties, little is known beyond Sauvage and co-workers' original reports. This may be at least in part because passive metal template approaches typically give rise to ligands that coordinatively saturate a bound metal 
ion, reducing their relevance to, for example, catalytic applications. In 2006, Leigh and co-workers introduced the active template approach, ${ }^{14}$ which relies on a kinetic metal templating effect. ${ }^{14 c}$ As such, the geometric properties of the metal binding pocket in active-template derived products are more diverse, allowing access to interlocked ligands with a range of denticities.

Here we report a series of active template-derived rotaxane-based ligands and their binding with representative $1^{\text {st }}$ row transition metal ions. We demonstrate that the mechanical bond allows access to complexes that are unavailable from the corresponding non-interlocked components. In turn, the unusual structures of some of the complexes produced is reflected in their electron paramagnetic resonance (EPR) spectroscopic parameters and electrochemical behavior, suggesting the potential to tailor the properties of metal ions using the mechanical bond.

Scheme 1. (a) Synthesis of rotaxane ligands 4-6. (b) structures of non-interlocked analogues 7-10.
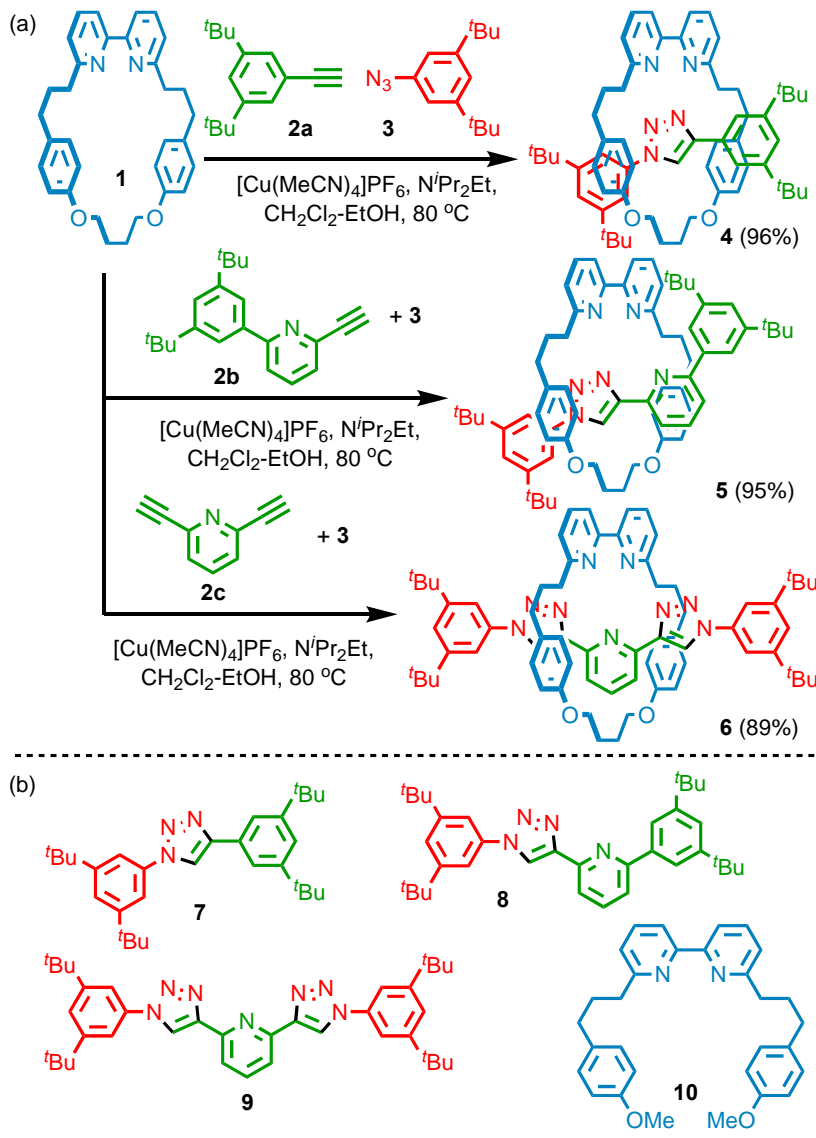

\section{- SYNTHESIS OF A FAMILY OF ROTAXANE LIGANDS}

Whereas Sauvage and co-workers' initial reports focused on catenane-based ligands, ${ }^{13}$ we set out to investigate the effect of the mechanical bond in rotaxanes as these are typically easier to access than the corresponding catenanes and are thus of potentially higher practical relevance. Furthermore, despite some interesting lead results that demonstrate that the mechanical bond in rotaxanes can affect various properties of complexed metal ions, ${ }^{15}$ no detailed investigation of the properties of rotaxane-based metal complexes has been reported. ${ }^{16}$ Rotaxanes 4,5 and 6 which present nominally tri-, tetra- and penta-dentate endohedral coordination environments respectively, were synthesized from readily available alkynes 2a-c, macrocycle $\mathbf{1}^{17}$ and azide 3 using our small macrocycle modifica$\operatorname{tion}^{18}$ of the active template $\mathrm{Cu}$-mediated alkyne-azide cycloaddition (AT-CuAAC) ${ }^{19}$ reaction. The corresponding non-interlocked axles 7-9 and 10, an acyclic equivalent of $\mathbf{1}$, were synthesized separately for comparison.

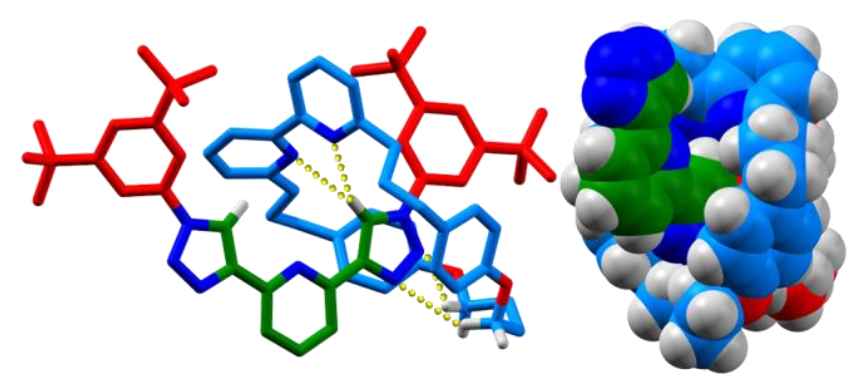

Figure 1. SCXRD structure of rotaxane 6 in capped sticks and space-filling ( $\mathrm{N}$-aryl substituent of front triazole ring removed for clarity) representations. Selected interaction distances $(\AA)$ : $\mathrm{H}_{d} \cdots \mathrm{N}$ 2.52, $\mathrm{H}_{d} \cdots \mathrm{N}$ 2.66, $\mathrm{H}_{I} \cdots \mathrm{N} 2.47, \mathrm{H}_{I} \cdots \mathrm{N}$ 2.82. Interstitial solvent and the majority of $\mathrm{H}$ atoms have been omitted for clarity.

Ligands 4-10 were isolated and fully characterized (see ESI). The most striking feature of the ${ }^{1} \mathrm{H}$ NMR spectra of rotaxanes 4-6 when compared with their non-interlocked axles, is that the triazole protons resonate at significantly higher $\mathrm{ppm}$, indicative of a $\mathrm{C}-\mathrm{H} \cdots \mathrm{N}$ hydrogen bond to the bipyridine $\mathrm{N}$ donors, as has previously been observed in sterically crowded AT-CuAAC-derived products. ${ }^{18}$ Single crystal x-ray diffraction (SCXRD) analysis of $\mathbf{5}$ and $\mathbf{6}$ confirmed this interaction in the solid state (Figure S13o and 1 respectively). ${ }^{20}$ The steric crowding provided by the mechanical bond is well demonstrated in the truncated spacefilling representation of $\mathbf{6}$ which clearly shows the congested nature of the rotaxane cavity.

\section{- COORDINATION CHEMISTRY OF ROTAXANES 4-6 AND THEIR NON-INTERLOCKED COMPONENTS.}

In order to compare the coordination chemistry of interlocked ligands 4-6 with their non-interlocked counterparts we selected $\mathrm{Co}^{\mathrm{II}}, \mathrm{Ni}^{\mathrm{II}}, \mathrm{Cu}^{\mathrm{II}}$ and $\mathrm{Zn}^{\mathrm{II}}$ in light of their differing coordination preferences and redox chemistries. The complexes formed with interlocked ligands 4-6 were compared with those formed with the corresponding non-interlocked components 7-10, in suitable equimolar mixtures to simulate the binding motifs of the rotaxanes.

Mixtures of non-interlocked ligands 7-10. Equimolar mixtures of the non-interlocked axles and bipyridine ligand $\mathbf{1 0}^{21}$ were titrated with $\mathrm{M}\left(\mathrm{ClO}_{4}\right)_{2}$ in $\mathrm{MeCN}$ (see ESI for full details; note $\mathrm{ClO}_{4}^{-}$salts are potentially explosive and 
should be handled with care and on small scales) and the metal-binding process was followed by UV-vis spectroscopy and ${ }^{1} \mathrm{H}$ NMR ( $\mathrm{Zn}^{\mathrm{II}}$ only).

Ligands $\mathbf{7}$ and $\mathbf{8}$ were found to be weakly coordinating with all of the metal ions investigated ${ }^{22}$ and thus, unsurprisingly, when an equimolar mixture of 10 with either 7 or 8 was titrated with $\mathrm{Co}^{\mathrm{II}}, \mathrm{Cu}^{\mathrm{II}}$ or $\mathrm{Zn}^{\mathrm{II}}$ the binding isotherms up to 0.5 equivalents resemble that of 10 alone, suggesting that heteroleptic complex formation is disfavored in these cases. ${ }^{23}$ The selective formation of $\left[\mathrm{Zn}(\mathbf{1 0})_{2}\right]^{2+}$ up to 0.5 equiv. of metal ion was confirmed in the case of $\mathrm{Zn}^{2+}$ by ${ }^{1} \mathrm{H}$ NMR analysis, with a complex mixture of species was observed to form over 0.5 equiv. of the $\mathrm{Zn}^{\mathrm{II}}$ (Figure $\mathrm{S}_{33}$ ).

In contrast, titration of an equimolar mixture of tridentate ligand 9 and bipyridine 10 revealed changes consistent with the formation of $\left[\mathrm{M}(9)_{2}\right]^{2+}$ between o and 0.5 equivalents for $\mathrm{M}=\mathrm{Ni}^{\mathrm{II}}$, $\mathrm{Co}^{\mathrm{II}}$ and $\mathrm{Zn}^{\mathrm{II}}$. Interestingly, ${ }^{1} \mathrm{H} \mathrm{NMR}$ analysis of the mixture 9 and 10 with iterative addition of $\mathrm{Zn}^{\mathrm{II}}$ suggested that a complex mixture was formed at all stoichiometries that included $[\mathrm{Zn}(\mathbf{9})(\mathbf{1 0})]^{2+}$ as a minor component (Figure $\mathrm{S}_{3} 6$ ). Only in the case of $\mathrm{Cu}^{\mathrm{II}}$ was a binding isotherm with a single turning point at 1 equiv. of metal ion observed, suggesting the selective formation of $[\mathrm{Cu}(\mathbf{9})(\mathbf{1 0})]^{2+}$.

Based on these results it appears that, except in the case of $\mathrm{Cu}^{\mathrm{II}}$ in combination with $\mathbf{9}$ and $\mathbf{1 0}$, the formation of heteroleptic complexes equivalent to rotaxanes 4-6 is disfavored for mixtures of the corresponding non-interlocked ligands with, at best, selective complexation of one of the ligand components, particularly at low ligand : metal stoichiometries, and at worst, complex mixtures being formed.

Table 1. Speciation ${ }^{a}$ of equimolar mixtures of ligand 10 with one of 7,8 or 9 in the presence of $\mathrm{M}\left(\mathrm{ClO}_{4}\right)_{2}$ determined by UV-vis titration ${ }^{b}$ and ${ }^{1} \mathrm{H}$ NMR ( $\mathrm{Zn}^{\mathrm{II}}$ only).

\begin{tabular}{|c|c|c|c|c|}
\hline & \multicolumn{4}{|c|}{ Metal ion } \\
\hline Ligands & $\mathrm{Co}^{\mathrm{II}}$ & $\mathrm{Ni}^{\mathrm{II}}$ & $\mathrm{Cu}^{\mathrm{II}}$ & $\mathrm{Zn}^{\mathrm{II}}$ \\
\hline $7+10$ & {$\left[\mathrm{Co}(\mathbf{1 0})_{\mathrm{n}}\right]^{2+c}$} & {$\left[\mathrm{Ni}(\mathbf{1 0})_{\mathrm{n}}\right]^{2+c}$} & {$\left[\mathrm{Cu}(\mathbf{1 0})_{2}\right]^{2+}$} & {$\left[\mathrm{Zn}(\mathbf{1 0})_{2}\right]^{2+}$} \\
\hline $8+10$ & {$\left[\mathrm{Co}(\mathbf{1 0})_{\mathrm{n}}\right]^{2+c}$} & n.d. ${ }^{c}$ & {$\left[\mathrm{Cu}(\mathbf{1 0})_{2}\right]^{2+}$} & {$\left[\operatorname{Zn}(10)_{2}\right]^{2+}$} \\
\hline $9+10$ & {$\left[\mathrm{Co}(\mathbf{9})_{2}\right]^{2+}$} & {$\left[\mathrm{Ni}(\mathbf{9})_{2}\right]^{2+}$} & {$[\mathrm{Cu}(\mathbf{9})(\mathbf{1 0})]^{2+}$} & $\begin{array}{l}\text { Complex } \\
\text { mixture }^{d}\end{array}$ \\
\hline
\end{tabular}

${ }^{a}$ Speciation refers to the major identifiable species formed during the titration, typically between o and 0.5 equiv. of added metal ion. Additional coordination sites are assumed to be occupied by solvent. ${ }^{b} \mathrm{UV}$-vis titrations were performed in $\mathrm{CH}_{3} \mathrm{CN}$ (0.04 mM, $298 \mathrm{~K}$ ). ${ }^{c}$ Changes consistent with metal binding were observed but speciation could not be determined. ${ }^{d} \mathrm{UV}$-vis suggested the initial formation of $\left[\mathrm{Zn}(\mathbf{9})_{2}\right]^{2+}$ but ${ }^{1} \mathrm{H}$ NMR demonstrated the formation of complex mixture of products at all ligand : metal stoichimetries.
Tridentate rotaxane 4. Interlocked tridentate ligand 4 was subjected to UV-Vis titration and found to coordinate strongly to $\mathrm{Cu}^{\mathrm{II}}$ and $\mathrm{Zn}^{\mathrm{II}}$ in a $1: 1$ stoichiometry $\left(K_{\mathrm{a}}>10^{6} \mathrm{M}^{-}\right.$ ${ }^{1}$, Figures $\mathrm{S} 83$ and $\left.\mathrm{S}_{105}\right),{ }^{24}$ but much more weakly to $\mathrm{Co}^{\mathrm{II}}$ or $\mathrm{Ni}^{\mathrm{II}}$ (Figures $\mathrm{S}_{43}$ and $\mathrm{S}_{63}$ ), ${ }^{25}$ which is in keeping with their weaker binding with bipyridine ligand 10 . SCXRD analysis of crystals of $\left[\mathrm{Cu}^{\mathrm{II}}(4)\right]\left(\mathrm{ClO}_{4}\right)_{2}$ confirmed that, although non-interlocked ligand $\mathbf{7}$ alone is weakly coordinating, ${ }^{22}$ the metal ion is coordinated by the bipyridine and triazole $\mathrm{N}$-donors (Figure 2a). In the solid state, molecules of $\mathrm{H}_{2} \mathrm{O}$ and $\mathrm{MeCN}$ complete the primary coordination sphere of the $\mathrm{Cu}^{\mathrm{II}}$ ion with the $\mathrm{ClO}_{4}$ anions interacting in the second sphere by $\mathrm{H}$-bonds to the coordinated $\mathrm{H}_{2} \mathrm{O}$. Similarly, the solid-state structure of $\left[\mathrm{Zn}^{\mathrm{II}}(\mathbf{4})\right](\mathrm{OTf})_{2}$ revealed a mechanically chelated complex (Figure $2 \mathrm{~b}$ ), albeit in this case an OTf anion is found in the primary coordination sphere along with a molecule of $\mathrm{H}_{2} \mathrm{O}$. Titration of 4 with $\mathrm{Zn}\left(\mathrm{ClO}_{4}\right)_{2}$ monitored by ${ }^{1} \mathrm{H}$ NMR revealed shifts consistent with the triazole donor participating in the binding event, strongly suggesting the triazole-metal interaction is maintained in solution (Figure S26).

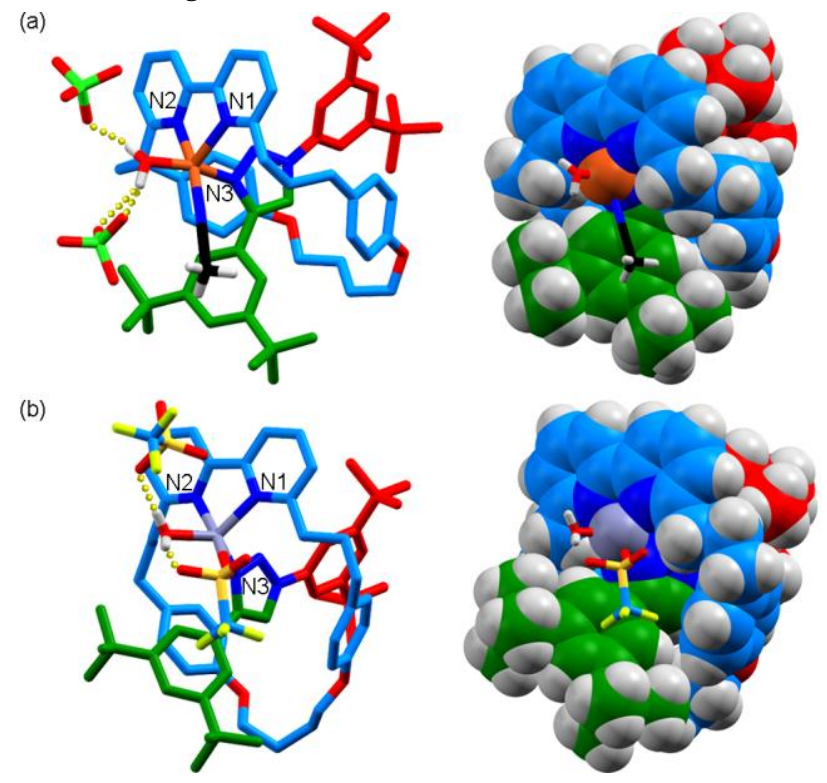

Figure 2. SCXRD structures with selected distances $(\AA)$ and angles $\left({ }^{\circ}\right)$ in sticks representation (selected interaction indicated) and space-filling representation (additional ligands in sticks representation, second sphere anions removed for clarity) of (a) $\left[\mathrm{Cu}^{\mathrm{II}}(4)\right]\left(\mathrm{ClO}_{4}\right)_{2}\left(\mathrm{~N}_{1} \cdots \mathrm{Cu} 2.29, \mathrm{~N}_{2} \cdots \mathrm{Cu} 1.97, \mathrm{~N}_{3} \cdots \mathrm{Cu}\right.$ 2.03, $\mathrm{MeCN} \cdots \mathrm{Cu} 1.99, \mathrm{H}_{2} \mathrm{O} \cdots \mathrm{Cu}$ 1.98; $\mathrm{MeCN} \cdots \mathrm{Cu} \cdots \mathrm{N}_{2}$ 171, $\mathrm{H}_{2} \mathrm{O} \cdots \mathrm{Cu} \cdots \mathrm{N}_{3} 165$; (b) $\left[\mathrm{Zn}^{\mathrm{II}}(4)\right](\mathrm{OTf})_{2}\left(\mathrm{~N}_{1} \cdots \mathrm{Zn} 2.13, \mathrm{~N}_{2} \cdots \mathrm{Zn}\right.$ 2.08, $\mathrm{N}_{5} \cdots 2.05$, TfO $\cdots 2.14, \mathrm{H}_{2} \mathrm{O} \cdots \mathrm{Zn} 2.04 ; \mathrm{H}_{2} \mathrm{O} \cdots \mathrm{Zn} \cdots \mathrm{N}_{2} 126$, $\mathrm{TfO} \cdots \mathrm{Zn} \cdots \mathrm{N}_{5}$ 87.56). Interstitial solvent and the majority of $\mathrm{H}$ atoms have been omitted for clarity.

Although in both cases rotaxane 4 offers a tridentate $f a c$ coordination mode, reminiscent of a scorpionate ligand, ${ }^{2}$ the coordination geometries of $\left[\mathrm{Cu}^{\mathrm{II}}(4)\right]\left(\mathrm{ClO}_{4}\right)_{2}$ and $\left[\mathrm{Zn}^{\mathrm{II}}(4)\right](\mathrm{OTf})_{2}$ are subtly different with $\mathrm{Cu}^{\mathrm{II}}$ adopting a distorted square based pyramidal structure $(\tau=0.09)$ whereas as $\mathrm{Zn}^{\mathrm{II}}$ is found in a distorted trigonal bipyramidal 
geometry $(\tau=0.64) .{ }^{26}$ In both cases, their solid-state structures in space filling representation (Figure 2) demonstrate the sterically crowded nature of the metal coordination sphere, with the smaller $\mathrm{H}_{2} \mathrm{O}$ ligand occupying the least congested position, allowing the $\mathrm{C}$-aryl substituent of the triazole to twist slightly in order to accommodate the larger $\mathrm{MeCN}\left(\mathrm{Cu}^{\mathrm{II}}\right)$ or $\mathrm{TfO}\left(\mathrm{Zn}^{\mathrm{II}}\right)$ ligand.

Thus, although rotaxane 4 offers a tridentate $\mathrm{N}$-donor set, similar to non-interlocked ligand 9, which binds strongly to all the metals studied,,$^{22}$ the mechanical bond precludes coordination numbers above five. This may provide an explanation for the weak binding of $\mathrm{Co}^{\mathrm{II}}$ and $\mathrm{Ni}^{\mathrm{II}}$; although $\mathrm{Cu}^{\mathrm{II}}$ and $\mathrm{Zn}^{\mathrm{II}}$ are often found with coordination numbers $<6, \mathrm{Co}^{\mathrm{II}}$ and $\mathrm{Ni}^{\mathrm{II}}$ are more typically found in hexacoordinate environments with weak-field ligands.

Tetradentate rotaxane 5. UV-vis titration of tetradentate rotaxane $\mathbf{5}$ with each metal ion in turn revealed similar behavior to that of rotaxane 4, although in this case strong binding $\left(K_{\mathrm{a}}>10^{6} \mathrm{M}^{-1}\right)$ to form a $1: 1$ complex was observed for $\mathrm{Co}^{\mathrm{II}}, \mathrm{Cu}^{\mathrm{II}}$ and $\mathrm{Zn}^{\mathrm{II}}$ with only $\mathrm{Ni}^{\mathrm{II}}\left(K_{\mathrm{a}}=1.3 \times 10^{4} \mathrm{M}^{-1}\right)$ binding weakly (Figures $\mathrm{S}_{51}, \mathrm{~S}_{71}$, S91 and $\mathrm{S}_{113}$ ). This stoichiometry was further confirmed by ${ }^{1} \mathrm{H}$ NMR in the case of $\mathrm{Zn}^{\mathrm{II}}$ (Figure $\mathrm{S}_{30}$ ).

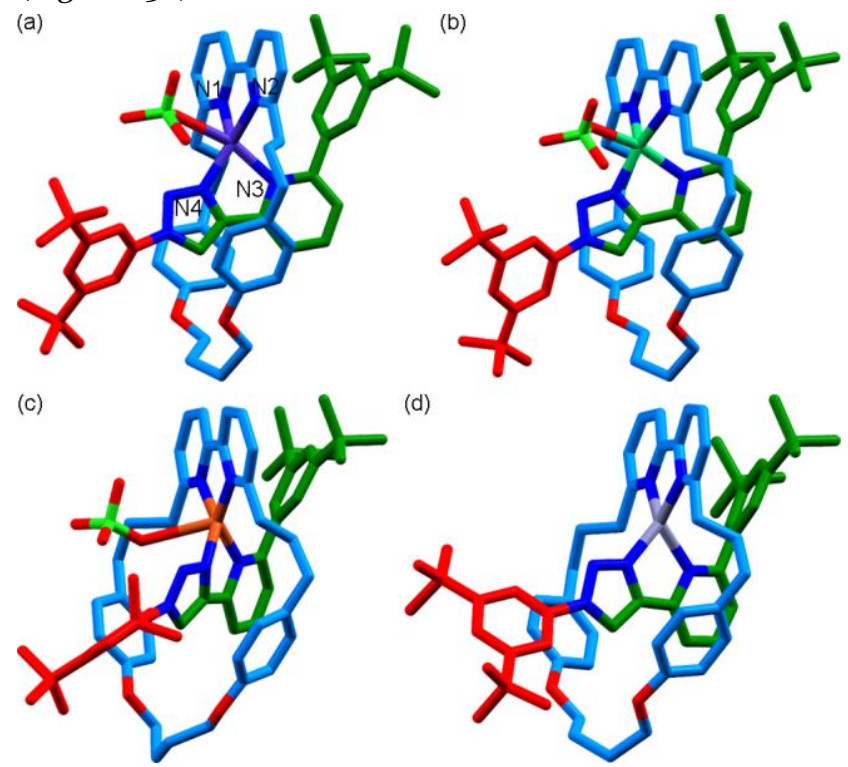

Figure 3. SCXRD structures ${ }^{27}$ with selected interaction lengths $(\AA)$ and angles $\left(^{\circ}\right)$ of: (a) $\left[\mathrm{Co}^{\mathrm{II}}(5)\right]\left(\mathrm{ClO}_{4}\right)_{2}\left(\mathrm{~N}_{1} \cdots \mathrm{Co} 2.00\right.$, $\mathrm{N}_{2} \cdots$ Co $2.00, \mathrm{~N}_{3} \cdots$ Co $2.10, \mathrm{~N}_{4} \cdots$ Co $1.98, \mathrm{O}_{3} \mathrm{ClO} \cdots$ Co 2.35 ; $\mathrm{N} 2 \cdots \mathrm{Co} \cdots \mathrm{N} 4140.75, \mathrm{O}_{3} \mathrm{ClO} \cdots \mathrm{Co} \cdots \mathrm{N} 3$ 161.5; angle between N1CoN2 and N3CoN4 plane 79.1); (b) $\left[\mathrm{Ni}^{\mathrm{II}}(5)\right]\left(\mathrm{ClO}_{4}\right)_{2}\left(\mathrm{~N}_{1} \cdots \mathrm{Ni}\right.$ 2.02, N2 $\cdots \mathrm{Ni} 1.98, \mathrm{~N}_{3} \cdots \mathrm{Ni} 2.11, \mathrm{~N}_{4} \cdots \mathrm{Ni} 2.00, \mathrm{O}_{3} \mathrm{ClO} \cdots \mathrm{Ni} 2.12$; $\mathrm{N} 2 \cdots \mathrm{Co} \cdots \mathrm{N} 4140.75, \mathrm{O}_{3} \mathrm{ClO} \cdots \mathrm{Co} \cdots \mathrm{N} 3161.5$; angle between $\mathrm{N} 1 \mathrm{NiN} 2$ and N3NiN4 plane 78.5$)$, (c) $\left[\mathrm{Cu}^{\mathrm{II}}(\mathbf{5})\right]\left(\mathrm{ClO}_{4}\right)_{2}\left(\mathrm{~N}_{1} \cdots \mathrm{Cu}\right.$ 1.97, $\mathrm{N}_{2} \cdots \mathrm{Cu} 1.97, \mathrm{~N}_{3} \cdots \mathrm{Cu} 2.01, \mathrm{~N}_{4} \cdots \mathrm{Cu} 1.96, \mathrm{O}_{3} \mathrm{ClO} \cdots \mathrm{Cu} 2.70$; angle between $\mathrm{N} 1 \mathrm{CuN} 2$ and $\mathrm{N} 3 \mathrm{CuN} 4$ plane $=51)$, (d) $\left[\mathrm{Zn}^{\mathrm{II}}(5)\right]\left(\mathrm{ClO}_{4}\right)_{2}\left(\mathrm{~N}_{1} \cdots \mathrm{Zn} \quad 1.98, \quad \mathrm{~N}_{2} \cdots \mathrm{Zn} \quad 1.99, \mathrm{~N}_{3} \cdots \mathrm{Zn} 2.07\right.$, $\mathrm{N}_{4} \cdots \mathrm{Zn} 1.97$; angle between $\mathrm{N} 1 \mathrm{ZnN} 2$ and $\mathrm{N} 3 \mathrm{ZnN} 4$ plane $=78.0$ ). $\mathrm{H}$ atoms, non-coordinated anions and interstitial solvent have been omitted for clarity.

Solid state structures were obtained by SCXRD analysis of $[\mathrm{M}(5)]\left(\mathrm{ClO}_{4}\right)_{2}$ for all of the metal ions (Figure 3) and these confirm that the rotaxane provides a tetradentate binding motif with the bipyridine and pyridine-triazole units prevented from adopting a coplanar orientation by the mechanical bond. The structures of $\left[\mathrm{Co}^{\mathrm{II}}(5)\right]\left(\mathrm{ClO}_{4}\right)_{2}$ and $\left[\mathrm{Ni}^{\mathrm{II}}(5)\right]\left(\mathrm{ClO}_{4}\right)_{2}$ are similar, with one $\mathrm{ClO}_{4}$ acting as the fifth ligand in a pentacoordinate structure. However, they exist at different points on the continuum between trigonal bipyramidal and square based pyramidal geometries with both metals significantly distorted from an ideal arrangement ( $\tau=0.35$ and 0.19 for $\mathrm{Co}^{\mathrm{II}}$ and $\mathrm{Ni}^{\mathrm{II}}$ respectively). In contrast $\left[\mathrm{Zn}^{\mathrm{II}}(5)\right]\left(\mathrm{ClO}_{4}\right)_{2}$ adopts a regular tetrahedral geometry in the solid state with no additional coordination of exogenous ligands.

Most strikingly, the structure of $\left[\mathrm{Cu}^{\mathrm{II}}(5)\right]\left(\mathrm{ClO}_{4}\right)_{2}$ can be described as a highly distorted tetrahedron with a very long contact ( $>95 \%$ of van der Waal's radii) between $\mathrm{Cu}^{\mathrm{II}}$ and the single inner-sphere perchlorate anion and an angle of $\sim 50^{\circ}$ between the chelating units of the axle and macrocycle. The mechanical bond thus appears to prevent the metal ion adopting a typical coordination geometry for $\mathrm{Cu}^{\mathrm{II}}$ with the metal ion "stuck" somewhere between the preferred coordination numbers and geometries of $\mathrm{Cu}^{\mathrm{II}}$ and $\mathrm{Cu}^{\mathrm{I}}$. This effect is reminiscent of that of the active site of a Type II center in copper proteins, in which the metal ion is bound by four N/O donors, in a quasi-square planar arrangement, with a fifth (and sometimes sixth), weakly coordinating distal ligand providing stabilization of the $\mathrm{Cu}^{\mathrm{II}}$ oxidation state; a well-known member of the Type II family is the $\mathrm{Cu}, \mathrm{Zn}$ dismutase in which the square pyramidal coordination geometry of the $\mathrm{Cu}$ consists of four histidines and an additional water ligand. ${ }^{28}$

Pentadentate rotaxane 6. Pentadentate ligand 6 was found by UV-vis titration to have a high affinity for all metal ions investigated with strong $1: 1$ binding $\left(K_{\mathrm{a}}>10^{6}\right.$ $\mathrm{M}^{-1}$ ) observed and confirmed by ${ }^{1} \mathrm{H}$ NMR in the case of $\mathrm{Zn}^{\mathrm{II}}$ (Figure $\mathrm{S}_{34}$ ). Crystals suitable for SCXRD analysis were obtained of $[\mathrm{Co}(6)]\left(\mathrm{ClO}_{4}\right)_{2},[\mathrm{Ni}(6)]\left(\mathrm{ClO}_{4}\right)_{2},[\mathrm{Cu}(6)]\left(\mathrm{ClO}_{4}\right)_{2}$ and $[\mathrm{Zn}(6)]\left(\mathrm{ClO}_{4}\right)_{2}{ }^{29}$ (Figure 4a-d respectively), allowing their structures to be compared. Perhaps surprisingly, given their different coordination preferences, all of the metal ions exhibit an extremely similar pentadentate, square-based pyramidal coordination geometry with $\tau$ values of $0.05,^{30} 0.02,0.03$ and 0.12 respectively with no exogenous ligand binding and the $\mathrm{ClO}_{4}$ ions disordered throughout the lattice. Thus, despite the relatively weakfield nature of the pyridine and triazole donors, the mechanical bond appears to enforce a 5-coordinate environment even in the cases of $\mathrm{Co}^{\mathrm{II}}$ and $\mathrm{Ni}^{\mathrm{II}}$ with no binding of exogenous ligands or anions permitted. To our knowledge these are the first examples of 5 -coordinate $\mathrm{Co}^{\mathrm{II}}$ and $\mathrm{Ni}^{\mathrm{II}}$ complexes of all neutral heteroaromatic N-donors. ${ }^{31}$ 
(a)

(b)

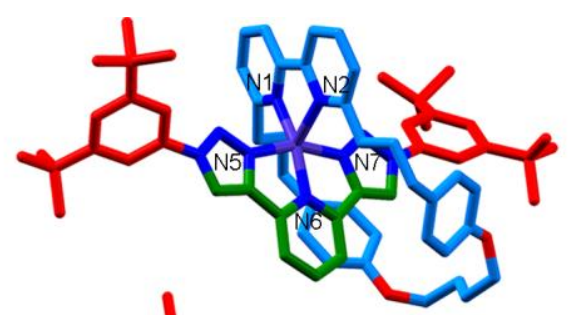

(c)

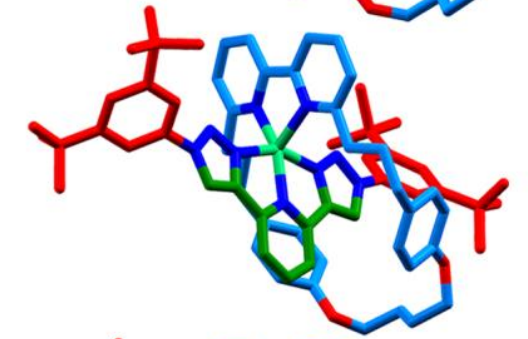

(d)
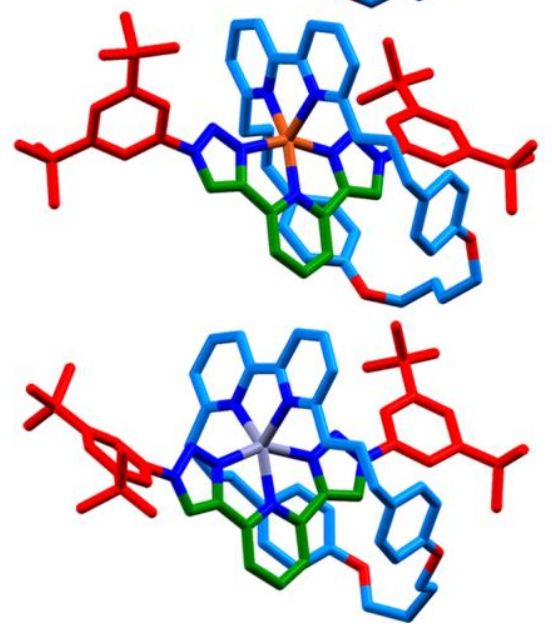

Figure 4. SCXRD structures ${ }^{27}$ with selected interaction lengths ( $(\AA)$ and angles $\left(^{\circ}\right)$ of: (a) $\left[\mathrm{Co}^{\mathrm{II}}(6)\right]\left(\mathrm{ClO}_{4}\right)_{2}\left(\mathrm{~N}_{1} \cdots \mathrm{Co} 1.96\right.$, $\mathrm{N}_{2} \cdots \mathrm{Co}$ 2.10, $\mathrm{N}_{5} \cdots \mathrm{Co}$ 1.98, N6‥Co $1.93, \mathrm{~N}_{7} \cdots \mathrm{Co}$ 1.96; $\mathrm{N}_{1} \cdots \mathrm{Co} \cdots \mathrm{N} 6$ 163.2, $\mathrm{N}_{5} \cdots \mathrm{Co} \cdots \mathrm{N}_{7}$ 16o.1; angle between $\mathrm{N}_{1} \mathrm{CoN} 2$ and $\mathrm{N}_{5} \mathrm{~N}_{6 \mathrm{~N}} \mathrm{C}$ Co planes 89.3); (b) [ $\left.\mathrm{Ni}^{\mathrm{II}}(6)\right]\left(\mathrm{ClO}_{4}\right)_{2}\left(\mathrm{~N}_{1} \cdots \mathrm{Ni} 2.00\right.$, $\mathrm{N}_{2} \cdots \mathrm{Ni} 2.02, \mathrm{~N}_{5} \cdots \mathrm{Ni} 2.10, \mathrm{~N} 6 \cdots \mathrm{Ni} 2.02, \mathrm{~N}_{7} \cdots \mathrm{Ni} 2.07$; $\mathrm{N}_{1} \cdots \mathrm{Ni} \cdots \mathrm{N} 6$ 156.5, $\mathrm{N}_{5} \cdots \mathrm{Ni} \cdots \mathrm{N}_{7}$ 155.4; angle between $\mathrm{N}_{1} \mathrm{NiN}_{2}$ and $\mathrm{N}_{5} \mathrm{~N}_{6} \mathrm{~N}_{7} \mathrm{Ni}$ planes 88.8); (c) $\left[\mathrm{Cu}^{\mathrm{II}}(6)\right]\left(\mathrm{ClO}_{4}\right)_{2} \quad\left(\mathrm{~N}_{1} \cdots \mathrm{Cu} 2.01\right.$, $\mathrm{N}_{2} \cdots \mathrm{Cu} \quad 2.14, \quad \mathrm{~N}_{5} \cdots \mathrm{Cu} \quad 2.03, \quad \mathrm{~N} 6 \cdots \mathrm{Cu}$ 1.97, $\mathrm{N}_{7} \cdots \mathrm{Cu}$ 2.01; $\mathrm{N}_{1} \cdots \mathrm{Cu} \cdots \mathrm{N} 6$ 159.1, $\mathrm{N}_{5} \cdots \mathrm{Cu} \cdots \mathrm{N}_{7}$ 157.3; angle between $\mathrm{N}_{1} \mathrm{CuN} 2$ and $\mathrm{N}_{5} \mathrm{~N}_{6} \mathrm{~N}_{7} \mathrm{Cu}$ planes 89.9$)$; d) $\left[\mathrm{Zn}^{\mathrm{II}}(\mathbf{6})\right]\left(\mathrm{ClO}_{4}\right)_{2}{ }^{29} \mathrm{H}$ atoms, non-coordinated anions and interstitial solvent have been omitted for clarity.

Coordination chemistry - conclusions. The UV-vis and ${ }^{1} \mathrm{H}$ NMR titrations of rotaxanes 4-6 with $\mathrm{M}\left(\mathrm{ClO}_{4}\right)_{2}$ and their comparison with the corresponding non-interlocked ligands, alongside the solid-state structures obtained, clearly demonstrate the ability of the mechanical bond to enforce the formation of complexes the non-interlocked equivalent of which are inaccessible under the same conditions. In contrast, in their original work, Sauvage and co-workers were able to access non-interlocked equivalents to their catenane-based metal complexes for most of the metals studied as the catenane coordination environment was equivalent to a simple "homoleptic"12 bis-phenanthroline complex. ${ }^{13 \mathrm{C}}$ The mechanical bond also enhances the binding properties of otherwise poorly coordinating ligand fragments $\mathbf{7}$ and $\mathbf{8}$, which participate in the formation of interlocked complexes but are weakly bound individually.

However, the sterically crowded binding site appears to enforce a compromise between this mechanical chelate effect, which is expected to enhance binding, and the exclusion of exogenous ligands, which results in coordination numbers $<6$ and, as a consequence, weak binding of rotaxane 4 with $\mathrm{Co}^{\mathrm{II}}$ and $\mathrm{Ni}^{\mathrm{II}}$. The ability of the mechanical bond to exclude additional ligands is perhaps most obvious in the cases of $[\mathrm{Co}(6)]\left(\mathrm{ClO}_{4}\right)_{2}$ and $[\mathrm{Ni}(6)]\left(\mathrm{ClO}_{4}\right)_{2}$ where a sixcoordinate complex might have been expected to form, although in this case the mechanical chelate effect of the pentadentate ligand ensures strong binding with all of the metal ions studied. Of the structures presented $\left[\mathrm{Cu}^{\mathrm{II}}(5)\right]\left(\mathrm{ClO}_{4}\right)_{2}$ is perhaps most striking, with the metal ion adopting a highly distorted tetrahedral geometry reminiscent of the Type II active site found in copper proteins. $^{28}$

\section{- ELECTRONIC AND REDOX PROPERTIES OF ROTAXANE-BASED METAL COMPLEXES}

With a set of interlocked metal complexes in hand we proceeded to investigate their electronic properties by continuous wave EPR and their redox properties by cyclic voltammetry (CV). These methods allowed us to confirm the nature of the complexes formed in solution and identify the effect of the mechanical bond on their electrochemical stability. To enable a direct comparison between the tri-, tetra- and pentadentate rotaxane ligands, we first focused on $\mathrm{Cu}^{\mathrm{II}}$ given that it is both paramagnetic and redox-active and forms stable complexes with rotaxane-based ligands 46.

$\mathrm{Cu}^{\mathrm{II}}$ complexes of rotaxanes $4-6$. The coordination environments of $\mathrm{Cu}$-rotaxane complexes $[\mathrm{Cu}(4)]\left(\mathrm{ClO}_{4}\right)_{2}$, $[\mathrm{Cu}(5)]\left(\mathrm{ClO}_{4}\right)_{2}$ and $[\mathrm{Cu}(6)]\left(\mathrm{ClO}_{4}\right)_{2}$ in solution were characterized by EPR spectroscopy (Figure 5) and compared with those predicted based on their solid-state structures (Figure 4). Solid-state EPR spectra were also acquired (Figure S159) which show that, besides the expected linebroadening, no significant changes occur compared to the frozen-solution spectra. This demonstrates that the metal centers remain magnetically dilute in the solid state and validates the comparison of structures determined by SCXRD with frozen-solution EPR spectra. All frozen-solution $\mathrm{Cu}^{\mathrm{II}}$ spectra exhibit axial or slightly rhombic anisotropy, with $g_{\mathrm{z}}>g_{\mathrm{y}} \approx g_{\mathrm{x}}$ indicative of the unpaired electron on $\mathrm{Cu}^{\text {II }}$ being located in the $d_{\left(x^{2}-y^{2}\right)}$ orbital. ${ }^{22}$ The interaction of the unpaired electron with the copper nucleus $(I=3 / 2)$ gives rise to four hyperfine peaks, three of which are clearly visible in the $g_{\mathrm{z}}$ region of each spectrum (the $4^{\text {th }}$ hyperfine peak of $A_{\mathrm{z}}$ is masked by the $g_{\mathrm{x}, \mathrm{y}}$ line, which is broad due to the unresolved $A_{x, y}$ hyperfine coupling).

The EPR spectrum of pentacoordinate $[\mathrm{Cu}(6)]\left(\mathrm{ClO}_{4}\right)_{2}$ is fully consistent with the solid state structure obtained by SCXRD (Figure 4c) with $g_{\mathrm{z}}=2.239$ and hyperfine parameter $A_{\mathrm{z}}=472 \mathrm{MHz}$, similar to previously reported analogous 
systems (Figure 5),33 and in keeping the values typically reported for Type II Cu centers in proteins. ${ }^{28 a}$ Furthermore, non-interlocked complex $[\mathrm{Cu}(\mathbf{9})(\mathbf{1 0})]\left(\mathrm{ClO}_{4}\right)_{2}$ presents an extremely similar EPR spectrum $\left(g_{\mathrm{z}}=2.241, A_{\mathrm{z}}=471 \mathrm{MHz}\right)$ confirming that, as implied by UV-vis analysis, pentacoordinate rotaxane $\mathbf{6}$ and the non-interlocked ligands 9 and $\mathbf{1 0}$ provide essentially identical coordination environments for $\mathrm{Cu}^{\mathrm{II}}$. In contrast to the SCXRD data, the EPR spectrum of $[\mathrm{Cu}(5)]\left(\mathrm{ClO}_{4}\right)_{2}$, in which the rotaxane provides a tetracoordinate binding site, reveals values of $g$ and $A$ consistent with similar systems characterized by tetracoordinate $\mathrm{Cu}^{\mathrm{II}} .3^{18,33}$ Thus, the EPR data reveal that the $[\mathrm{Cu}(\mathbf{5})]\left(\mathrm{ClO}_{4}\right)_{2}$ structure appears to be highly fluxional in solution: the weakly bound perchlorate ion in the first coordination sphere of $\mathrm{Cu}^{\mathrm{II}}$ in the solid-state structure of $[\mathrm{Cu}(5)]\left(\mathrm{ClO}_{4}\right)_{2}$ (Figure $3 \mathrm{c}$ ) is lost in solution, inducing a structural change from the penta- to tetracoordinated complex.

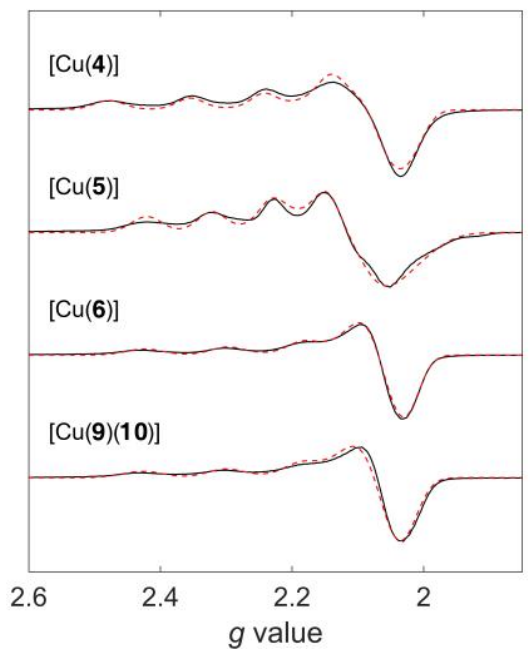

Figure 5. X-band EPR spectra of $[\mathrm{Cu}(4)],[\mathrm{Cu}(5)],[\mathrm{Cu}(\mathbf{6})]$ and $[\mathrm{Cu}(\mathbf{9})(\mathbf{1 0})]$ at $100 \mathrm{~K}$ (black) and simulations (dashed red lines). EPR spectra were scaled by power, receiver gain, number of scans and frequency. Simulation of the experimental data were performed with Easyspin:34 $[\mathrm{Cu}(4)]: g_{\mathrm{x}}=2.105, g_{\mathrm{y}}=2.042$, $g_{\mathrm{z}}=2.297, A_{\mathrm{x}}=50 \mathrm{MHz}, A_{\mathrm{y}}=80 \mathrm{MHz}, A_{\mathrm{z}}=452 \mathrm{MHz}$. $[\mathrm{Cu}(5)]:$ $g_{\mathrm{x}}=2.125, g_{\mathrm{y}}=2.044, g_{\mathrm{z}}=2.272, A_{\mathrm{x}}=90 \mathrm{MHz}, A_{\mathrm{y}}=112 \mathrm{MHz}, A_{\mathrm{z}}$ $=373 \mathrm{MHz}$. $[\mathrm{Cu}(\mathbf{6})]: g_{\mathrm{x}}=2.07 \mathrm{o}, g_{\mathrm{y}}=2.07 \mathrm{O}, g_{\mathrm{z}}=2.239, A_{\mathrm{x}}=30$ $\mathrm{MHz}, A_{\mathrm{y}}=30 \mathrm{MHz}, A_{\mathrm{z}}=472 \mathrm{MHz}$. $[\mathrm{Cu}(\mathbf{9})(\mathbf{1 0})]: g_{\mathrm{x}}=2.075, g_{\mathrm{y}}$ 2.075, $g_{\mathrm{z}}=2.241, A_{\mathrm{x}}=-30 \mathrm{MHz}, A_{\mathrm{y}}=-30 \mathrm{MHz}, A_{\mathrm{z}}=471 \mathrm{MHz}$. Linewidth $3 \mathrm{mT}$. $A_{\mathrm{x}, \mathrm{y}}$ values are an upper limit of the hyperfine coupling and were estimated from the peak-to-peak linewidth for the $g_{x y}$ peak divided by 4 .

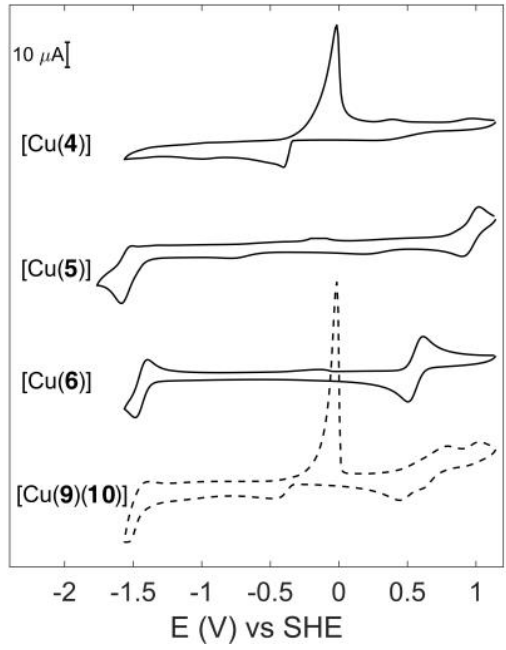

Figure 6. $\mathrm{CV}$ of $[\mathrm{Cu}(4)],[\mathrm{Cu}(5)],[\mathrm{Cu}(6)]$ and $[\mathrm{Cu}(\mathbf{9})(\mathbf{1 0})]$. Reduction potentials for the $\mathrm{Cu}^{\mathrm{I} / \mathrm{II}}$ redox couple are $+0.959 \mathrm{~V}$ and $+0.559 \mathrm{~V}$ and reduction potentials for the ligand-based redox couple are $-1.498 \mathrm{~V}$ and $-1.439 \mathrm{~V}$ for $[\mathrm{Cu}(5)]$ and $[\mathrm{Cu}(6)]$, respectively.

Compared to the square pyramidal $[\mathrm{Cu}(6)]\left(\mathrm{ClO}_{4}\right)_{2}$, $[\mathrm{Cu}(5)]\left(\mathrm{ClO}_{4}\right)_{2}$ exhibits an increased $g_{\mathrm{z}}$ and a decreased $A_{\mathrm{z}}$ (Figure 5), consistent with the predictions of ligand-field theory; a square pyramidal geometry induces a larger energy splitting between the SOMO (singly occupied molecular orbital) and the close-lying $d$-orbitals than the energy difference that is typically expected for tetrahedral geometries. Because the deviation of $g$ from $g_{\mathrm{e}}$ is inversely proportional to the energy gap between the SOMO and the fully-occupied $d$ orbitals, $g_{\mathrm{z}}$ is expected to be closer to $g_{\mathrm{e}}$ in the pentacoordinate complex. 35

The trend in $g$ and $A$ is not entirely followed by the nominally tricoordinate $[\mathrm{Cu}(4)]\left(\mathrm{ClO}_{4}\right)_{2} ; g_{\mathrm{z}}$ is consistent with a lower coordination number whereas $A_{\mathrm{z}}$ is consistent with the higher, pentacoordinate structure found in the solid state. This apparently less well-defined geometry is in keeping with the $\mathrm{CV}$ experiments (see below) and perhaps unsurprising as in the solid state the fourth and fifth coordination sites are filled by labile solvent molecules and in solution this structure is likely to be highly fluxional. The values of $g$ and $A$ obtained from simulations of the $[\mathrm{Cu}(4)]\left(\mathrm{ClO}_{4}\right)_{2}$ EPR spectrum are in good agreement with those previously reported for the similar complex $[\mathrm{Cu}(\mathrm{bipy})(\mathrm{py})]$ which, although nominally tricoordinate, was demonstrated by EPR to be four coordinate in solution. ${ }^{32}$ 


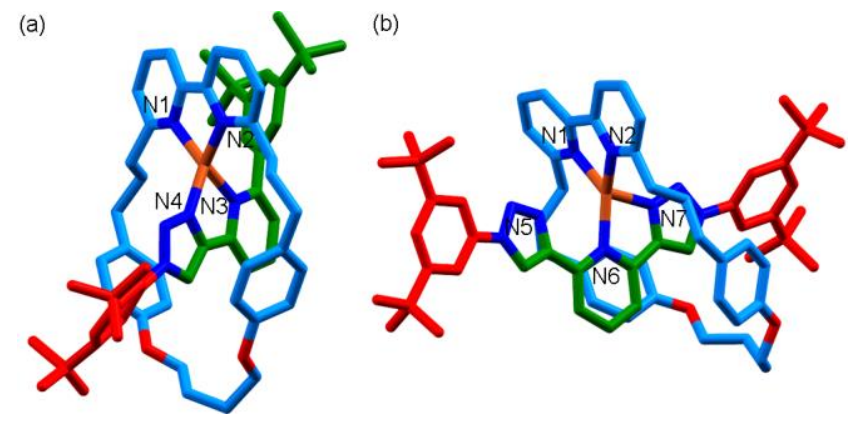

Figure 7. SCXRD structures with selected interaction lengths $(\AA)$ and angles $\left(^{\circ}\right)$ of: $(\mathrm{a})\left[\mathrm{Cu}^{\mathrm{I}}(5)\right]\left(\mathrm{PF}_{6}\right)\left(\mathrm{N}_{1} \cdots \mathrm{Cu} 2.00, \mathrm{~N}_{2} \cdots \mathrm{Cu}\right.$ 2.01, $\mathrm{N}_{3} \cdots \mathrm{Cu}$ 2.06, $\mathrm{N}_{4} \cdots \mathrm{Cu} 2.00$; angle between $\mathrm{N}_{1} \mathrm{CuN} 2$ and $\mathrm{N}_{3} \mathrm{CuN} 4$ planes 78.7$)$; (b) $\left[\mathrm{Cu}^{\mathrm{I}}(6)\right]\left(\mathrm{ClO}_{4}\right)_{2} \quad\left(\mathrm{~N}_{1} \cdots \mathrm{Cu}\right.$ 2.04, $\mathrm{N}_{2} \cdots \mathrm{Cu} \quad 2.03, \quad \mathrm{~N}_{5} \cdots \mathrm{Cu} \quad 2.85, \quad \mathrm{~N} 6 \cdots \mathrm{Cu} \quad 2.04, \mathrm{~N}_{5} \cdots \mathrm{Cu}$ 2.11; $\mathrm{N}_{1} \cdots \mathrm{Ni} \cdots \mathrm{N} 6$ 132.9, $\mathrm{N}_{5} \cdots \mathrm{Ni} \cdots \mathrm{N}_{7}$ 148.43; angle between $\mathrm{N}_{1 C u N}$ and $\mathrm{N}_{5} \mathrm{~N}_{6} \mathrm{~N}_{7} \mathrm{Cu}$ planes 87.0 . $\mathrm{H}$ atoms, non-coordinated anions and interstitial solvent have been omitted for clarity.

Having clarified the solution state structures of $\left[\mathrm{Cu}\left(4^{-}\right.\right.$ 6)] $\left(\mathrm{ClO}_{4}\right)_{2}$ by EPR, we turned our attention to the effect that their structures have on their electrochemical properties. The cyclic voltammograms of $[\mathrm{Cu}(4)]\left(\mathrm{ClO}_{4}\right)_{2}$, $[\mathrm{Cu}(5)]\left(\mathrm{ClO}_{4}\right)_{2}$ and $[\mathrm{Cu}(6)]\left(\mathrm{ClO}_{4}\right)_{2}$ show a striking difference in their reduction potentials, as well as in the reversibility of the redox events (Figure 6).

Both $[\mathrm{Cu}(5)]\left(\mathrm{ClO}_{4}\right)_{2}$ and $[\mathrm{Cu}(\mathbf{6})]\left(\mathrm{ClO}_{4}\right)_{2}$ exhibit one reversible process $\left(E_{\mathrm{m}}=+0.959 \mathrm{~V}\right.$ and $+0.559 \mathrm{~V}$, respectively) that are assigned to a $\mathrm{Cu}^{\mathrm{II} / \mathrm{I}}$ process on the basis of EPRmonitored electrolysis experiments at different controlled potentials $\left(\mathrm{S}_{163}\right)$. The $\mathrm{CVs}$ of $[\mathrm{Cu}(5)]\left(\mathrm{ClO}_{4}\right)_{2}$ and $[\mathrm{Cu}(6)]\left(\mathrm{ClO}_{4}\right)_{2}$ reveal a further reversible redox process with $E_{\mathrm{m}}=-1.498 \mathrm{~V}$ and $-1.439 \mathrm{~V}$, respectively, that is not observed in $[\mathrm{Cu}(4)]\left(\mathrm{ClO}_{4}\right)_{2}$. Similar reduction events were observed in the case of $[\mathrm{Zn}(5)]\left(\mathrm{ClO}_{4}\right)_{2}$ (Figure S155) and $[\mathrm{Zn}(6)]\left(\mathrm{ClO}_{4}\right)_{2}$ (Figure $\left.\mathrm{S}_{153}\right)$ suggesting that this process is ligand centered..$^{6}$ No redox event was observed for the ligand frameworks in the absence of any metal (Figure S156), suggesting that the electron withdrawing effect of the metal ion activates the ligands to reduction.

In contrast, no reversible $\mathrm{Cu}^{\mathrm{II} / \mathrm{I}}$ couple is observed for $[\mathrm{Cu}(4)]\left(\mathrm{ClO}_{4}\right)_{2}$. Instead, an irreversible process is visible for the $\mathrm{Cu}^{1 / \mathrm{o}}$ redox couple, where the reduction occurring at $-0.470 \mathrm{~V}$ in the cathodic sweep is followed by oxidative stripping that results in a large anodic peak at $-0.015 \mathrm{~V}$, as has previously been observed for other $\mathrm{Cu}^{\mathrm{I}}$ complexes. ${ }^{37}$ This suggests that the $\mathrm{Cu}^{\mathrm{I}}$ complex of tridentate ligand 4 is unstable under these conditions, and indeed, UV-vis titration of 4 with $\left[\mathrm{Cu}(\mathrm{MeCN})_{4}\right] \mathrm{PF}_{6}$ revealed weak binding $\left(K_{\mathrm{a}}\right.$ $\left.\sim 10^{4} \mathrm{M}^{-1}\right)$. These results suggest that 4 is unable to stabilize both $\mathrm{Cu}^{\mathrm{I}}$ and $\mathrm{Cu}^{\mathrm{II}}$ which leads in turn to chemical irreversibility under reducing conditions.

The significant difference in the reduction potentials of the $\mathrm{Cu}^{\mathrm{II} / \mathrm{I}}$ couple $(\sim 40 \mathrm{O} \mathrm{mV})$ between tetradentate ligand 5 and pentadentate ligand $\mathbf{6}$ is unsurprising given the coordination preferences of $\mathrm{Cu}$ in different oxidation states.33 Indeed, rotaxanes 5 and $\mathbf{6}$ resemble the phenanthroline and terpyridine "stations" used in Sauvage and co-workers original electrochemically driven shuttle with molecular motion triggered by $\mathrm{Cu}^{1 / I I}$ redox cycling..$^{8}$ Thus, tetradentate rotaxane 5 provides an ideal binding site for $\mathrm{Cu}^{\mathrm{I}}$ and this is reflected in the high redox potential of the $\mathrm{Cu}^{\mathrm{I} / \mathrm{II}} \mathrm{cou}$ ple. The facile formation of $\mathrm{Cu}^{\mathrm{I}}$ is again analogous to copper enzymes in which strong distortion from tetrahedral geometry in the entatic state leads to unusually high reduction potentials. 5 The solid state structure of $[\mathrm{Cu}(5)]\left(\mathrm{PF}_{6}\right)$ obtained by SCXRD (Figure 7a) emphasizes how well suited this ligand is for the tetrahedral metal center.

Conversely, it might be expected that pentadentate ligand $\mathbf{6}$ is better suited to binding $\mathrm{Cu}^{\mathrm{II}}$ which would result in a lower value of $E_{\mathrm{m}}$, as observed. However, the reduction potential of $[\mathrm{Cu}(6)]\left(\mathrm{ClO}_{4}\right)_{2}$ is not particularly low, as might be expected for a ligand that could be considered optimized for $\mathrm{Cu}^{\mathrm{II}}$, suggesting that $\mathrm{Cu}^{\mathrm{I}}$ is also well accommodated. The ability of nominally pentadentate ligand 6 to accommodate $\mathrm{Cu}^{\mathrm{I}}$ was confirmed in the solid state by $\mathrm{x}$-ray analysis (Figure $7 \mathrm{~b}$ ); $\mathbf{6}$ provides a four-coordinate environment suitable for $\mathrm{Cu}^{\mathrm{I}}$ by allowing the metal to be displaced to one end of the binding pocket. Thus, pentadentate ligand $\mathbf{6}$ is flexible enough to readily accommodate $\mathrm{Cu}$ in either oxidation state resulting in reversible redox behavior at a moderate value of $E_{\mathrm{m}}$. Indeed, the binding constant of 6 with $\mathrm{Cu}^{1}$ is still remarkably high $\left(K_{\mathrm{a}}>10^{6} \mathrm{M}^{-1}\right)$, highlighting that although this pentadentate mechanically chelating ligand is rigid enough to enforce a five-coordinate environment on $\mathrm{Co}^{\mathrm{II}}$ and $\mathrm{Ni}^{\mathrm{II}}$, it is still flexible enough to accommodate lower valent metals.

Finally, the electrochemical stability of $[\mathrm{Cu}(\mathbf{9})(\mathbf{1 0})]\left(\mathrm{ClO}_{4}\right)_{2}$ is dramatically lower than that of $[\mathrm{Cu}(\mathbf{6})]\left(\mathrm{ClO}_{4}\right)_{2}$ (Figure 6). Whereas, the $\mathrm{Cu}^{\mathrm{I} / \mathrm{II}}$ couple is fully reversible for the interlocked ligand, the $[\mathrm{Cu}(\mathbf{9})(\mathbf{1 0})]\left(\mathrm{ClO}_{4}\right)_{2}$ voltammogram cannot be assigned unambiguously. The ligand-centered reduction is not fully reversible and the $\mathrm{Cu}^{\mathrm{I} / \mathrm{I}}$ couple appears to be split into two semi-reversible steps whose reduction potentials are remarkably similar to those of $[\mathrm{Cu}(5)]\left(\mathrm{ClO}_{4}\right)_{2}$ and $[\mathrm{Cu}(6)]\left(\mathrm{ClO}_{4}\right)_{2}$. Together with the UV-vis speciation experiments and the EPR data, we tentatively conclude that the non-interlocked heteroleptic complex $[\mathrm{Cu}(\mathbf{9})(\mathbf{1 0})]\left(\mathrm{ClO}_{4}\right)_{2}$ undergoes ligand disproportionation - most likely to homoleptic complex $\left[\mathrm{Cu}(\mathbf{1 0})_{2}\right]^{+}-$on reduction whereas the interlocked structure prevents such reorganization for $[\mathrm{Cu}(6)]\left(\mathrm{ClO}_{4}\right)_{2}$. Thus, even though EPR measurements and $\mathrm{UV}$-vis titrations suggest that $[\mathrm{Cu}(\mathbf{6})]^{2+}$ and $[\mathrm{Cu}(\mathbf{9})(\mathbf{1 0})]^{2+}$ are structurally extremely similar, their electrochemical properties are significantly different; as a result of the mechanical bond the interlocked metal complex is dramatically more robust, allowing it to undergo electrochemical manipulation without degradation.

Taken together, the results of the $\mathrm{Cu}$ complexes show how the coordination environment, corroborated through EPR measurements, alter the redox processes occurring on the metal center. As highlighted by the pentacoordinate 
complexes, the rotaxane ligand clearly enhances the electrochemical reversibility of the $\mathrm{Cu}^{\mathrm{II} / \mathrm{I}}$ redox couple in the interlocked scaffold with respect to the non-interlocked counterpart.

Electronic and Redox Properties of $[\mathrm{Co}(6)]^{2+}$. The EPR spectrum of pentacoordinate $[\mathrm{Co}(6)]\left(\mathrm{ClO}_{4}\right)_{2}$ suggests that the complex exists as a mixture of low-spin and high-spin states, with the fast-relaxing high-spin signal only visible at temperatures as low as $12 \mathrm{~K}$ (Figure 8, S162). The lowspin signal of $[\mathrm{Co}(6)]\left(\mathrm{ClO}_{4}\right)_{2}$ displays a rhombic $g$ tensor, with an eight-line hyperfine splitting on $g_{\mathrm{z}}$ due to the interaction of the unpaired electron with the $\mathrm{Co}^{\mathrm{II}}$ nucleus ( $I$ $=7 / 2)$. A superhyperfine coupling is also detectable along $g_{z}\left(A_{z}=42 \mathrm{MHz}\right)$, arising from the interaction of the unpaired electron with one of the surrounding ${ }^{14} \mathrm{~N}$ nuclei. Apart from minor differences in the $g$ values, the hyperfine couplings with the ${ }^{59} \mathrm{Co}$ and ${ }^{14} \mathrm{~N}$ nuclei are in good agreement with those reported for square pyramidal cobalt porphyrins, where the ${ }_{5} \mathrm{~N}$ coordination is provided by the addition of an imidazole ligand. ${ }^{39}$ Our results thus suggest that the solution-phase structure of $[\mathrm{Co}(6)]\left(\mathrm{ClO}_{4}\right)_{2}$ is similar to the solid state, with no additional exogenous ligands coordinating to the metal center.

$\mathrm{N}$-pentacoordinate $\mathrm{Co}^{\mathrm{II}}$ complexes are not common. Among those reported, the high-spin configuration is most frequently observed; $4^{\circ}$ indeed coordination numbers lower than six typically stabilize the high-spin state. ${ }^{00 \mathrm{~b}, 41}$ There are however examples of low-spin $\mathrm{Co}^{\mathrm{II}}$ with a ${ }_{5} \mathrm{~N}$ coordination, e.g. tetradentate macrocyclic ligands such as tetraazacyclododecane ${ }^{3 \mathrm{~h}}$ and tetraazacyclotetradecadiene ${ }^{3 \mathrm{~b}}$ in the presence of a fifth ligand. Thus, although both spin configurations are known to be accessible for $\mathrm{Co}^{\mathrm{II}}$ pentacoordinate structures, including trigonal bipyramidal, square pyramidal and intermediate geometries, ${ }^{42}$ the observed mixture of spin states in $[\mathrm{Co}(6)]\left(\mathrm{ClO}_{4}\right)_{2}$ is unusual. Double integration of the low-spin signal at $100 \mathrm{~K}$ under strictly non-saturating conditions led to a spin quantification of $2.87 \pm 0.06 \mathrm{mM}$ for a sample with a $10 \mathrm{mM}$ nominal concentration suggesting an approximate ratio of $3.5: 1$ high to low-spin. A detailed study of the magnetic properties of this complex is ongoing but outside the scope of this paper.

Cyclic voltammetry of $[\mathrm{Co}(6)]\left(\mathrm{ClO}_{4}\right)_{2}$ reveals two reversible redox processes at $-0.395 \mathrm{~V}$ and $-1.481 \mathrm{~V}$, assigned to the $\mathrm{Co}^{\mathrm{II} / \mathrm{I}}$ couple and to the ligand framework, respectively (Figure 9).43 Although complexes of $\mathrm{Co}^{\mathrm{II}}$ with pyridyl donors are usually able to undergo electrochemical oxidation to $\mathrm{Co}^{\mathrm{III}}, 44$ no $\mathrm{Co}^{\mathrm{III} / \mathrm{II}}$ redox couple was observed for $[\mathrm{Co}(6)]\left(\mathrm{ClO}_{4}\right)_{2}$. The inaccessibility of the $\mathrm{Co}^{\mathrm{III}}$ oxidation state is consistent with Sauvage and co-workers original report in which a catenane ligand was found to prevent access to higher oxidation states by inhibiting ligand reorganization, and a similar effect was recently observed in the context of a $\mathrm{Co}^{\mathrm{II}}$ complex of the sterically hindered ligand neocuprine, ${ }^{45}$ but this is the first time to our knowledge that a similar effect has been observed in the context of a rotaxane. ${ }^{13 \mathrm{c}}$

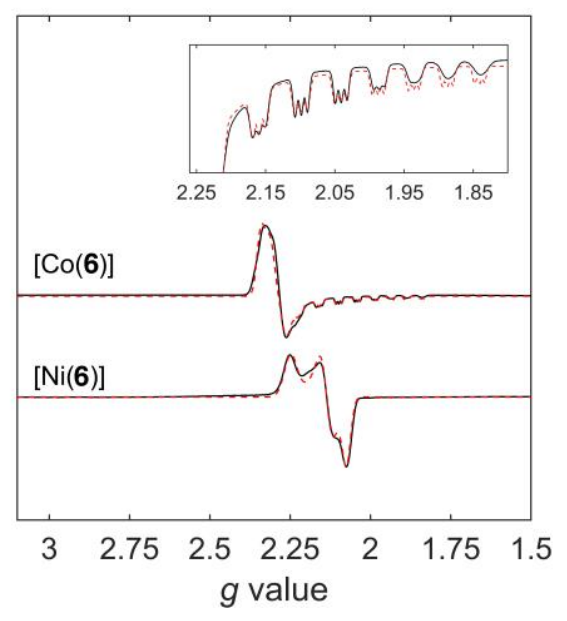

Figure 8. X-band EPR spectra of $[\mathrm{Co}(6)]$ and $[\mathrm{Ni}(6)]$ at $100 \mathrm{~K}$. EPR measurements of $[\mathrm{Co}(6)]$ were carried out in $\mathrm{CH}_{2} \mathrm{Cl}_{2}$. Simulations (red) of the experimental data (black) were performed with Easyspin. $34[\mathrm{Co}(6)]: g_{\mathrm{x}}=\mathbf{2 . 2 9 8}, g_{\mathrm{y}}=\mathbf{2 . 2 7 8}, g_{\mathrm{z}}=$ 2.014, $A_{\mathrm{x}}=20 \mathrm{MHz}, A_{\mathrm{y}}=20 \mathrm{MHz}, A_{\mathrm{z}}(59 \mathrm{Co})=260 \mathrm{MHz}, A_{\mathrm{z}}\left({ }^{14} \mathrm{~N}\right)$ $=42 \mathrm{MHz}$. $[\mathrm{Ni}(6)]: g_{\mathrm{x}}=2.137, g_{\mathrm{y}}=2.075, g_{\mathrm{z}}=2.249$. Linewidth $3.4 \mathrm{mT}$. Inset: superhyperfine splitting on the $g_{\mathrm{z}}$ region of $[\mathrm{Co}(6)]$ due to the interaction with one ${ }^{14} \mathrm{~N}$ nucleus $(I=1) . A_{\mathrm{x}, \mathrm{y}}$ values are an upper limit of the hyperfine coupling and were estimated from the peak-to-peak linewidth for the $g_{\mathrm{xy}}$ peak divided by 8 .

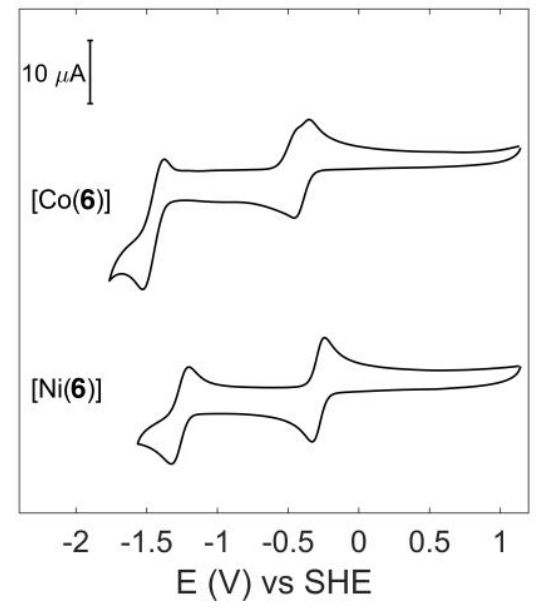

Figure 9. $\mathrm{CV}$ of $[\mathrm{Co}(6)]$ (in $\mathrm{CH}_{2} \mathrm{Cl}_{2}$ ) and $[\mathrm{Ni}(6)](\mathrm{MeCN})$. $\mathrm{Re}-$ duction potentials for the $\mathrm{M}^{\mathrm{I} / \mathrm{II}}$ redox couple are $-0.395 \mathrm{~V}$ and $-0.285 \mathrm{~V}$ and reduction potentials for the ligand-based redox couple are $-1.481 \mathrm{~V}$ and $-1.264 \mathrm{~V}$ for $[\mathrm{Co}(6)]$ and $[\mathrm{Ni}(6)]$, respectively.

The interlocked ligands thus prevent the oxidation to $\mathrm{Co}^{\mathrm{III}}$, otherwise a common feature of $\mathrm{Co}^{\mathrm{II}}$ complexes, as well as conferring a small energy gap between the highand low-spin states that results in an unusual mixture of the spin states being observed in solution. 
Electronic and Redox Properties of $[\mathrm{Ni}(6)]\left(\mathrm{ClO}_{4}\right)_{2}$. As in the case of the other metal rotaxane complexes, the electrochemical profile of pentacoordinate complex $[\mathrm{Ni}(6)]\left(\mathrm{ClO}_{4}\right)_{2}$ contains two reversible processes where the $\mathrm{Ni}^{\mathrm{II} / \mathrm{I}}$ redox couple occurs at $-0.285 \mathrm{~V}$ and the ligand-centered couple at $-1.264 \mathrm{~V}$ (Figure 9). The first reduction was assigned as a one-electron process of the metal on the basis of EPR studies performed on the electrochemically reduced $[\mathrm{Ni}(6)]\left(\mathrm{ClO}_{4}\right)_{2}$ sample; bulk electrochemical reduction of $[\mathrm{Ni}(6)]\left(\mathrm{ClO}_{4}\right)_{2}$ at $-0.350 \mathrm{~V}$ produced a dark blue solution with a typical $\mathrm{d}^{9} \mathrm{Ni}^{1}$ EPR spectrum and a well-defined rhombic $g$ tensor (Figure 8). No radical-like signal around $g=2.00$, which would be consistent with ligand centered reduction, was observed. ${ }^{6}$ Thus, electrolysis of the complex at $-0.350 \mathrm{~V}$ generated a $\mathrm{Ni}^{+}$reduction product in which the unpaired electron resides on the metal site rather than on the ligand moiety.

The electrochemical reduction of homoleptic complex $\left[\mathrm{Ni}(\mathbf{1 0})_{\mathrm{n}}\right]\left(\mathrm{ClO}_{4}\right)_{2}$ was also attempted, but no $\mathrm{Ni}^{\mathrm{I}}$ EPR signal was observed. The accessibility of the $\mathrm{Ni}^{\mathrm{I}}$ oxidation state in the case of $[\mathrm{Ni}(6)]\left(\mathrm{ClO}_{4}\right)_{2}$ thus appears to be a consequence of the mechanical bond, which allows access to a low-coordination number heteroleptic complex that is unavailable when the corresponding non-interlocked ligands are employed, and stabilizes the reduced state of the metal ion while preventing the dissociation of the complex. Furthermore, when a bulk sample of $[\mathrm{Ni}(6)]\left(\mathrm{ClO}_{4}\right)_{2}$ was reduced electrochemically in a Q-band EPR tube (I.D. $1.1 \mathrm{~mm}, 10 \mu \mathrm{L}$ ) and allowed to stand in ambient conditions, after one day the sample still retained the deep blue color indicative of the $\mathrm{Ni}^{\mathrm{I}}$ complex. Bubbling $\mathrm{O}_{2}$ through the sample resulted in immediate return to a pale-yellow solution, indicating rapid oxidation to the $\mathrm{Ni}^{\mathrm{II}}$ species. The steric bulk of the rotaxane framework thus appears to impose kinetic stability on the reduced $\mathrm{Ni}^{1}$ species, which was shown by EPR spectroscopy to have a metal-centered unpaired electron.

\section{- CONCLUSIONS}

The binding of rotaxane ligands and non-interlocked analogues to first row transition metals has been investigated in detail for the first time. The structures of these complexes in the solid state demonstrate the ability of the mechanical bond to enforce unusual coordination geometries and numbers that cannot be accessed in the non-interlocked case. EPR spectroscopic investigations allowed us to corroborate the solution state structures and the $g$ and $A$ values of the $\mathrm{Cu}$ complexes were shown to be sensitive probes of coordination geometry and its effect on the relative orbital energies of the systems. In the case of $\mathrm{Cu}^{\mathrm{II}}$-rotaxane complexes, cyclic voltammetry confirmed that the mechanical bond confers electrochemical and chemical reversibility on the $\mathrm{Cu}^{\mathrm{I} / \mathrm{II}}$ couple; even when the metal Applicable. Polyhedron 2018, 143, 11.

(2)

(a) Pettinari, C. Scorpionate Compounds. Eur. J. Inorg. coordination environment is identical, the mechanical bond prevents ligand reorganization during reduction/oxidation, analogous to the amino-acid framework in redox proteins that minimize reoganization energy to enable efficient electron transfer. As previously reported in the context of catenane-based metal complexes, rotaxane ligands proved to greatly enhance the stability of low oxidation states; the $\mathrm{Co}^{\mathrm{II} / \mathrm{III}}$ redox couple could not be observed in the case of pentadentate rotaxane $\mathbf{6}$ and for the corresponding $\mathrm{Ni}^{\mathrm{II}}$ complex, electrochemical reduction of the sample yielded a stable $\mathrm{Ni}^{\mathrm{I}}$ species (an oxidation state that is known to play an important role in Ni-containing enzymes) that could be detected by EPR.

Metal complexes of interlocked ligands have been reported widely since the development of passive template syntheses of mechanically interlocked molecules, but little attention has been given to the effect of the mechanical bond to the chemistry of the coordinated metal ion. Based on our results we propose that readily available rotaxane ligands represent an underexplored platform for the development of metal complexes for a range of applications in materials, inorganic medicinal chemistry and catalysis.

\section{- ASSOCIATED CONTENT}

\section{Supporting Information}

Full experimental details and characterization data, including SCXRD data where appropriate, for all novel compounds. All experimental details for electrochemical and EPR experiments. This material is available free of charge via the Internet at http://pubs.acs.org.

\section{- AUTHOR INFORMATION}

\section{Corresponding Author \\ *s.goldup@soton.ac.uk \\ *m.roessler@qmul.ac.uk}

\section{Author Contributions}

tThese authors contributed equally.

\section{- ACKNOWLEDGMENT}

The authors are grateful to Fluorochem for the gift of reagents. This work was supported financially by the Royal Society (Research Fellowship to SMG; SERB co-funded Newton International Fellowship to AKC), the European Union (Marie Skłodowska-Curie Fellowship to JEML, agreement No 660731), European Research Council (Consolidator Grant, agreement no. 724987) and the EPSRC (EP/Jo1981X/1). MC and MMR thank the Materials Research Institute (QMUL) for a studentship.

\section{- REFERENCES}

Chem. 2016, 2016, 2209. (b) Adach, A. Review: An Overview of Recent Developments in Coordination Chemistry of Polypyrazolylmethylamines. Complexes with N-Scorpionate 
Ligands Created in Situ from Pyrazole Derivatives and Zerovalent Metals. J. Coord. Chem. 2017, 70, 757. (a) Alexander, V. Design and Synthesis of Macrocyclic Ligands and Their Complexes of Lanthanides and Actinides. Chem. Rev. 1995, 95, 273. (b) Rezaeivala, M.; Keypour, H. Schiff Base and Non-Schiff Base Macrocyclic Ligands and Complexes Incorporating the Pyridine Moiety - The First 50 Years. Coord. Chem. Rev. 2014, 280, 203. (c) Gavey, E. L.; Pilkington, M. Coordination Complexes of 15-Membered Pentadentate Aza, Oxoaza and Thiaaza Schiff Base Macrocycles "Old Complexes Offer New Attractions." Coord. Chem. Rev. 2015, 296, 125. (d) Haque, A.; Ilmi, R.; Al-Busaidi, I. J.; Khan, M. S. Coordination Chemistry and Application of Mono- and Oligopyridine-Based Macrocycles. Coord. Chem. Rev. 2017, 350, 320. (e) Tseberlidis, G.; Intrieri, D.; Caselli, A. Catalytic Applications of Pyridine-Containing Macrocyclic Complexes. Eur. J. Inorg. Chem. 2017, 2017, 3589.

(4) An alternative approach using sterically hindered ligands, combined with the inate coordination preferences of the metal ion to control the formation of heteroleptic complexes and even generate complex, self-sorted mixtures has been developed by Schmittel and co-workers. Recent examples and reviews: (a) Goswami, A.; Schmittel, M. Heteroleptic Copper Phenanthroline Complexes in Motion: From StandAlone Devices to Multi-Component Machinery. Coord. Chem. Rev. 2018, 376, 478. (b) Biswas, P. K.; Saha, S.; Paululat, T.; Schmittel, M. Rotating Catalysts Are Superior: Suppressing Product Inhibition by Anchimeric Assistance in Four-Component Catalytic Machinery. J. Am. Chem. Soc. 2018, 140, 9038. (c) Schmittel, M. Networking Switches for Smart Functions Using Copper Signaling and Dynamic Heteroleptic Complexation. Dalt. Trans. 2018, 47, 6654. (d) Schmittel, M. From Self-Sorted Coordination Libraries to Networking Nanoswitches for Catalysis. Chem. Commun. 2015, 51, 14956. (e) Saha, M. L.; Neogi, S.; Schmittel, M. Dynamic Heteroleptic Metal-Phenanthroline Complexes: From Structure to Function. Dalt. Trans. 2014, 43, 3815. (f) Saha, M. L.; Schmittel, M. From 3-Fold Completive SelfSorting of a Nine-Component Library to a Seven-Component Scalene Quadrilateral. J. Am. Chem. Soc. 2013, 135, 17743. (g) Mahata, K.; Saha, M. L.; Schmittel, M. From an EightComponent Self-Sorting Algorithm to a Trisheterometallic Scalene Triangle. J. Am. Chem. Soc. 2010, 132, 15933.

(a) Vallee, B. L.; Williams, R. J. Metalloenzymes: The Entatic Nature of Their Active Sites. Proc. Natl. Acad. Sci. 1968, 59, 498. (b) Holm, R. H.; Kennepohl, P.; Solomon, E. I. Structural and Functional Aspects of Metal Sites in Biology. Chem. Rev. 1996, 96, 2239.

(6) For selected examples and reviews of synthetic complexes designed to display "entatic" behaviour see: (a) Comba, P. Coordination Compounds in the Entatic State. Coord. Chem. Rev. 200o, 200-202, 217. (b) Chaka, G.; Sonnenberg, J. L.; Schlegel, H. B.; Heeg, M. J.; Jaeger, G.; Nelson, T. J.; Ochrymowycz, L. A.; Rorabacher, D. B. A Definitive Example of a Geometric "Entatic State" Effect: Electron-Transfer Kinetics for a Copper(II/I) Complex Involving a Quinquedentate Macrocyclic Trithiaether - Bipyridine Ligand. J. Am. Chem. Soc. 2007, 129, 5217. (c) Hoffmann, A.; Binder, S.; Jesser, A.; Haase, R.; Flörke, U.; Gnida, M.; Salomone Stagni, M.; Meyer-Klaucke, W.; Lebsanft, B.; Grünig, L. E.; Schneider, S.; Hashemi, M.; Goos, A.; Wetzel, A.; Rübhausen, M.; Herres-Pawlis, S. Catching an Entatic State - A Pair of Copper Complexes. Angew. Chem. Int. Ed. 2014, 53, 299. (d) Garcia, L.; Cisnetti, F.; Gillet, N.; Guillot, R.; Aumont-Nicaise, M.; Piquemal, J. P.; Desmadril, M.; Lambert, F.; Policar, C. Entasis through Hook-and-Loop Fastening in a Glycoligand with Cumulative Weak Forces Stabilizing Cuㅍ. J. Am. Chem. Soc. 2015, 137, 1141. (e) Dahl, E.
W.; Szymczak, N. K. Hydrogen Bonds Dictate the Coordination Geometry of Copper: Characterization of a Square-Planar Copper(I) Complex. Angew. Chem. Int. Ed. 2016, 55, 3101. (f) Dicke, B.; Hoffmann, A.; Stanek, J.; Rampp, M. S.; Grimm-Lebsanft, B.; Biebl, F.; Rukser, D.; Maerz, B.; Göries, D.; Naumova, M.; Biednov, M.; Neuber, G.; Wetzel, A.; Hofmann, S. M.; Roedig, P.; Meents, A.; Bielecki, J.; Andreasson, J.; Beyerlein, K. R.; Chapman, H. N.; Bressler, C.; Zinth, W.; Rübhausen, M.; Herres-Pawlis, S. Transferring the Entatic-State Principle to Copper Photochemistry. Nat. Chem. 2018, 10, 355

(7) Dietrich-Buchecker, C. O.; Sauvage, J. P.; Kintzinger, J. P. Une Nouvelle Famille de Molecules : Les Metallo-Catenanes. Tetrahedron Lett. 1983, 24, 5095.

(8) For recent reviews on the role of metal ions in the synthesis of interlocked molecules see: (a) Beves, J. E.; Blight, B. A.; Campbell, C. J.; Leigh, D. A.; McBurney, R. T. Strategies and Tactics for the Metal-Directed Synthesis of Rotaxanes, Knots, Catenanes, and Higher Order Links. Angew. Chem. Int. Ed. 2011, 50, 926o. (b) Vukotic, V. N.; Loeb, S. J. Coordination Polymers Containing Rotaxane Linkers. Chem. Soc. Rev. 2012, 41, 5896. (c) Lewis, J. E. M.; Beer, P. D.; Loeb, S. J.; Goldup, S. M. Metal Ions in the Synthesis of Interlocked Molecules and Materials. Chem. Soc. Rev. 2017, 46, 2577.

(9) Selected reviews on the properties and applications of interlocked molecules: (a) Bruns, C. J.; Stoddart, J. F. The Nature of the Mechanical Bond: From Molecules to Machines; Wiley, 2016. (b) Leigh, D. A.; Gil-Ramírez, G. G.; Leigh, D. A.; Stephens, A. J.; Gil-Ramírez, G. G.; Leigh, D. A.; Stephens, A. J. Catenanes: Fifty Years of Molecular Links. Angew. Chem. Int. Ed. 2015, 54, 6110. (c) Xue, M.; Yang, Y.; Chi, X.; Yan, X.; Huang, F. Development of Pseudorotaxanes and Rotaxanes: From Synthesis to Stimuli-Responsive Motions to Applications. Chem. Rev. 2015, 115, 7398. (d) Erbas-Cakmak, S.; Leigh, D. A.; McTernan, C. T.; Nussbaumer, A. L. Artificial Molecular Machines. Chem. Rev. 2015, 115, 10081. (e) Evans, N. H.; Beer, P. D. Progress in the Synthesis and Exploitation of Catenanes since the Millennium. Chem. Soc. Rev. 2014, 43, 4658.

(10) Moran, J. R.; Karbach, S.; Cram, D. J. Cavitands: Synthetic Molecular Vessels. J. Am. Chem. Soc. 1982, 104, 5826.

(11) Zhang, X. X.; Izatt, R. M.; Bradshaw, J. S.; Krakowiak, K. E. Approaches to Improvement of Metal Ion Selectivity by Cryptands. Coord. Chem. Rev. 1998, 174, 179.

(12) Here "homoleptic" refers to the fact that both rings are identical, presenting the metal with identical phenanthroline ligands; given that a catenane is a single molecule, catenane complexes (where external ligands are excluded) are by definition homoleptic.

(13) (a) Dietrich-Buchecker, C. O.; Kern, J. M.; Sauvage, J. P. An Air-Stable $d^{9}$ nickel(I) Catenate: Stabilisation of Monovalent Nickel by Interlocked Macrocyclic Ligands. J. Chem. Soc. Chem. Commun. 1985, No. 12, 76o. (b) Albrecht-Gary, A. M.; Saad, Z.; Dietrich-Buchecker, C. O.; Sauvage, J. P. Interlocked Macrocyclic Ligands : A Kinetic Catenand Effect in Copper (I) Complexes. J. Am. Chem. Soc. 1985, 107, 3205. (c) Dietrich-Buchecker, C.; Sauvage, J. P.; Kern, J. M. Synthesis and Electrochemical Studies of Catenates: Stabilization of Low Oxidation States by Interlocked Macrocyclic Ligands. J. Am. Chem. Soc. 1989, 111, 7791. (d) Armaroli, N.; De Cola, L.; Balzani, V.; Sauvage, J.; DietrichBuchecker, C. O.; Kern, J.-M.; Bailal, A. Absorption and Emission Properties of a 2-Catenand, Its Protonated Forms, and Its Complexes with $\mathrm{Li}^{+}, \mathrm{Cu}^{+}, \mathrm{Ag}^{+}, \mathrm{Co}^{2+}, \mathrm{Ni}^{2+}, \mathrm{Zn}^{2+}, \mathrm{Pd}^{2+}$ and $\mathrm{Cd}^{2+}$ : Tuning of the Luminescence over the Whole 
Visible Spectral Region. J. Chem. Soc. Dalt. Trans. 1993, No. 21, 3241.

(14) (a) Crowley, J. D.; Goldup, S. M.; Lee, A.-L.; Leigh, D. A.; McBurney, R. T. Active Metal Template Synthesis of Rotaxanes, Catenanes and Molecular Shuttles. Chem. Soc. Rev. 2009, 38, 1530. (b) Saito, S. Synthesis of Interlocked Compounds Utilizing the Catalytic Activity of Macrocyclic Phenanthroline-Cu Complexes. J. Incl. Phenom. Macrocycl. Chem. 2015, 82, 437. (c) Denis, M.; Goldup, S. M. The Active Template Approach to Interlocked Molecules. Nat. Rev. Chem. 2017, 1, 0061.

(15) For selected examples see: (a) Davidson, G. J. E., Loeb, S. J. Dalton Trans. 2003, 4319. (b) Leigh, D. A.; Lusby, P. J.; Slawin, A. M. Z.; Walker, D. B. Rare and Diverse Binding Modes Introduced through Mechanical Bonding. Angew. Chem. Int. Ed. 2005, 44, 4557. (c) Davidson, G. J. E., Loeb, S. J., Passaniti, P., Silvi, S., Credi, A. Chem. - A Eur. J. 20o6, 12, 3233. (d) Winn, J.; Pinczewska, A.; Goldup, S. M. Synthesis of a Rotaxane $\mathrm{Cu}(\mathrm{I})$ Triazolide under Aqueous Conditions. J. Am. Chem. Soc. 2013, 135, 13318. (e) Noor, A.; Lo, W. K. C. C.; Moratti, S. C.; Crowley, J. D. CuAAC "Click" Active-Template Synthesis of Functionalised [2] Rotaxanes Using Small ExoSubstituted Macrocycles: How Small Is Too Small? Chem. Commun. 2014, 50, 7044. (f) Noor, A.; Moratti, S. C.; Crowley, J. D. Active-Template Synthesis of "Click" [2]Rotaxane Ligands: Self-Assembly of Mechanically Interlocked MetalloSupramolecular Dimers, Macrocycles and Oligomers. Chem. Sci. 2014, 5, 4283. (g) Galli, M.; Lewis, J. E. M.; Goldup, S. M. A Stimuli-Responsive Rotaxane-Gold Catalyst: Regulation of Activity and Diastereoselectivity. Angew. Chem. Int. Ed. 2015, 54, 13545. (h) Baggi, G.; Loeb, S. J. Rotationally Active Ligands: Dialing-Up the Co-Conformations of a [2] Rotaxane for Metal Ion Binding. Angew. Chem. Int. Ed. 2016, 55, 12533. (i) Ngo, T. H.; Labuta, J.; Lim, G. N.; Webre, W. A.; D'Souza, F.; Karr, P. A.; Lewis, J. E. M. M.; Hill, J. P.; Ariga, K.; Goldup, S. M. Porphyrinoid Rotaxanes: Building a Mechanical Picket Fence. Chem. Sci. 2017, 8, 6679. (j) Baggi, G.; Loeb, S. J. Rotationally Active Ligands: Dialing-Up Multiple Interlocked Co-Conformations for Silver(I) Coordination. Chem. - A Eur. J. 2017, 23, 14163.

(16) (a) Loeb, S. J. Rotaxanes as Ligands: From Molecules to Materials. Chem. Soc. Rev. 2007, 36, 226. (b) Lewis, J. E. M.; Galli, M.; Goldup, S. M. Properties and Emerging Applications of Mechanically Interlocked Ligands. Chem. Commun. 2016, 53, 298.

(17) Lewis, J. E. M.; Bordoli, R. J.; Denis, M.; Fletcher, C. J.; Galli, M.; Neal, E. A.; Rochette, E. M.; Goldup, S. M. High Yielding Synthesis of 2,2'-Bipyridine Macrocycles, Versatile Intermediates in the Synthesis of Rotaxanes. Chem. Sci. 2016, 7, 3154 .

(18) (a) Lahlali, H.; Jobe, K.; Watkinson, M.; Goldup, S. M. Macrocycle Size Matters: "Small" Functionalized Rotaxanes in Excellent Yield Using the CuAAC Active Template Approach. Angew. Chem. Int. Ed. 2011, 50, 4151. (b) Neal, E. A.; Goldup, S. M. Competitive Formation of Homocircuit [3]Rotaxanes in Synthetically Useful Yields in the BipyridineMediated Active Template CuAAC Reaction. Chem. Sci. 2015, 6, 2398. (c) Lewis, J. E. M.; Winn, J.; Cera, L.; Goldup, S. M. Iterative Synthesis of Oligo[ $\mathrm{n}$ ]Rotaxanes in Excellent Yield. J. Am. Chem. Soc. 2016, 138, 16329. (d) Neal, E. A.; Goldup, S. M. A Kinetic Self-Sorting Approach to Heterocircuit [3]Rotaxanes. Angew. Chem. Int. Ed. 2016, 55, 12488. (e) Lewis, J. E. M.; Winn, J.; Goldup, S. M. Stepwise, Protecting Group Free Synthesis of [4]Rotaxanes. Molecules 2017, 22, 89.

(19) (a) Aucagne, V.; Hänni, K. D.; Leigh, D. A.; Lusby, P. J.; Walker, D. B. Catalytic "Click" Rotaxanes: A Substoichiometric Metal-Template Pathway to Mechanically Interlocked Architectures. J. Am. Chem. Soc. 2006, 128, 2186. (b) Aucagne, V.; Berna, J.; Crowley, J. D.; Goldup, S. M.; Hänni, K. D.; Leigh, D. A.; Lusby, P. J.; Ronaldson, V. E.; Slawin, A. M. Z.; Viterisi, A.; Walker, D. B. Catalytic "ActiveMetal" Template Synthesis of [2]Rotaxanes, [3]Rotaxanes, and Molecular Shuttles, and Some Observations on the Mechanism of the $\mathrm{Cu}(\mathrm{i})$-Catalyzed Azide-Alkyne 1,3Cycloaddition. J. Am. Chem. Soc. 2007, 129, 11950.

(20) Although only one triazole $\mathrm{C}$ - $\mathrm{H}$ interacts with the bipyridine unit in the solid-state structure of $\mathbf{6}$, the solution-state ${ }^{1} \mathrm{H}$ NMR spectra appear highly symmetrical, consistent with rapid exchange of the macrocycle between triazole $\mathrm{C}-\mathrm{H}$ sites on the NMR timescale.

(21) We focussed on acyclic bipyridine 10 with axles 7-9 rather than unstoppered equivalents of the axles with macrocycle 1 as the small size of $\mathbf{1}$ disfavours formation of threaded pseudorotaxane complexes. For instance, titration of a mixture of $\mathbf{1}$ and $\mathbf{S}_{5}$, an analogue of $\mathbf{8}$ that lacks the ${ }^{t} \mathrm{Bu}$ groups, with $\mathrm{Zn}^{2+}$ monitored by ${ }^{1} \mathrm{H}$ NMR confirmed the formation of a complex mixture of products in which the threaded complex is disfavoured even though formation of the $\mathrm{Zn}^{2+}$ complex is extremely favourable in the case of rotaxane 5. See Figures S37-41.

(22) The non-interlocked components of rotaxanes 4-6 were titrated separately with $\mathrm{M}\left(\mathrm{ClO}_{4}\right)_{2}$ in $\mathrm{MeCN}$ and the metalbinding process was followed by UV-vis spectroscopy and ${ }^{1} \mathrm{H}$ NMR ( $\mathrm{Zn}^{\mathrm{II}}$ only) in order to establish their individual behavior. See ESI for further details.

(23) Speciation could not be determined in the titration of $10+8$ with $\mathrm{Ni}^{\mathrm{II}}$ which displays similar, weak binding with these ligands.

(24) At the concentrations of the UV-vis titrations $\left(4 \times 10^{-5} \mathrm{M}\right)$ it is not possible to accurately determine the binding constant for strongly binding ligands ((a) Hirose, K. A Practical Guide for the Determination of Binding Constants. J. Incl. Phenom. 2001, 39, 193. (b) Thordarson, P. Determining Association Constants from Titration Experiments in Supramolecular Chemistry. Chem. Soc. Rev. 2011, 40, 1305.) and these are thus reported as a lower limit of $K_{\mathrm{a}}>10^{6} \mathrm{M}^{-1}$.

(25) The binding isotherms of 4 with $\mathrm{Co}^{\mathrm{II}}$ or $\mathrm{Ni}^{\mathrm{II}}$ were poorly defined suggesting that protonation of the ligand competes with metal coordination. The alternative explanation, that complexes of the form $\left[\mathrm{M}(4)_{2}\right]^{2+}$ compete with the formation of $[\mathrm{M}(4)]^{2+}$ cannot be ruled out on the basis of the data available but is unlikely on steric grounds. For an example of a less sterically hindered $\mathrm{ML}_{2}$ complex of an interlocked ligands see ref. $15 \mathrm{c}$.

(26) The $\tau$ parameter measures the distortion from perfect trigonal bipyramidal $(\tau=1)$ or square pyramidal $(\tau=0)$ geometry: (a) Addison, A. W.; Rao, T. N.; Reedijk, J.; van Rijn, J.; Verschoor, G. C. Synthesis, Structure, and Spectroscopic Properties of Copper(II) Compounds Containing NitrogenSulphur Donor Ligands; the Crystal and Molecular Structure of Aqua[1,7-Bis(N-Methylbenzimidazol-2'-yl)-2,6Dithiaheptane]Copper(II) Pe. J. Chem. Soc., Dalt. Trans. 1984, No. 7, 1349. (b) Crans, D. C.; Tarlton, M. L.; McLauchlan, C. C. Trigonal Bipyramidal or Square Pyramidal Coordination Geometry? Investigating the Most Potent Geometry for Vanadium Phosphatase Inhibitors. Eur. J. Inorg. Chem. 2014, 2014, 4450.

(27) Where more than one complex appears in the asymmetric unit, one is chosen arbitrarily for display as in all cases they are essentially identical. The exception to this is $[\mathrm{Co}(6)]\left(\mathrm{ClO}_{4}\right)_{2}$ in which the two complexes in the asymmetric unit exhibit significant differences. $3^{\circ}$

(28) (a) Solomon, E. I.; Sundaram, U. M.; Machonkin, T. E. 
Multicopper Oxidases and Oxygenases. Chem. Rev. 1996, 96, 2563. (b) Solomon, E. I.; Hadt, R. G. Recent Advances in Understanding Blue Copper Proteins. Coord. Chem. Rev. 2011, 255, 774. (c) Rubino, J. T.; Franz, K. J. Coordination Chemistry of Copper Proteins: How Nature Handles a Toxic Cargo for Essential Function. J. Inorg. Biochem. 2012, 107, 129. (d) Solomon, E. I.; Heppner, D. E.; Johnston, E. M.; Ginsbach, J. W.; Cirera, J.; Qayyum, M.; Kieber-Emmons, M. T.; Kjaergaard, C. H.; Hadt, R. G.; Tian, L. Copper Active Sites in Biology. Chem. Rev. 2014, 114, 3659.

(29) The structure of $\left[\mathrm{Zn}(6)_{2}\right]\left(\mathrm{ClO}_{4}\right)_{2}$ could not be fully refined due to significant disorder. It is included here for completeness and clearly demonstrates the connectivity of the complex. The .cif file is available as supporting information but has not been deposited in the CCDC.

(30) Two Co complexes were found in the asymmetric unit of $[\mathrm{Co}(6)]\left(\mathrm{ClO}_{4}\right)_{2}$ with significantly different structural parameters that appear consistent with a $1: 1$ mixture of high-spin and low-spin metal centres. This requires further study for clarification but is consistent with the EPR data presented (Figure S16o). The structure presented in Figure 4a and parameters discussed here are for the structure with longer $\mathrm{Co}-\mathrm{N}$ contacts, presumed to be the high-spin complex at this stage.

(31) For selected examples of 5-coordinate complexes of $\mathrm{Co}^{\mathrm{II}}$ and $\mathrm{Ni}^{\mathrm{II}}$ with neutral $\mathrm{sp}^{3} \mathrm{~N}$ donors see: (a) Meier, P.; Merbach, A.; Bürki, S.; Kaden, T. A. Relatively Slow Water Exchange in a Pentaco-Ordinate Macrocyclic Cobalt(II) Complex. J. Chem. Soc., Chem. Commun. 1977, 36. (b) Goedken, V. L.; Kildahl, N. K.; Busch, D. H. Five-Coordinate Cobalt(II) Complexes of Macrocyclic Ligands - A New Reversible Oxygen Carrying System. J. Coord. Chem. 1977, 7, 89. (c) Curzon, E. H.; Herron, N.; Moore, P. Relative Labilities of Five-Co-Ordinate Mono(Acetonitrile)(1,4,8,11-Tetramethyl-1,4,8,11-TetraAzacyclotetradecane)-Nickel(II) and -Cobalt(II) Ions towards Associative Solvent Exchange. J. Chem. Soc. Dalt. Trans. 1980, No. 4, 574. (d) Bertini, I.; Canti, G.; Luchinat, C.; Messori, L. $1 \mathrm{H}$ NMR Detection of $\mathrm{CoOH}_{2} / \mathrm{CoOH}$ Interconversions in High-Spin Cobalt(II) Complexes. Inorg. Chem. 1982, 21, 3426. (e) Chandra, S.; Kumar, R. Spectral Studies, Cyclic Voltammetry and Synthesis of Cobalt(II) and Ruthenium(III) Complexes with Symmetric and Asymmetric Ring Containing Membered N2S2, N4, and N5donor Macrocyclic Ligands. Spectrochim. Acta - Part A Mol. Biomol. Spectrosc. 2005, 62, 1050. (f) Siegfried, L.; Kaden, T. A. Kinetic Studies of the on/off Reaction of the Amino Group in the Side Chain of $\mathrm{Cu}(\mathrm{II})$, $\mathrm{Ni}(\mathrm{II})$, and $\mathrm{Co}(\mathrm{II})$ Complexes with 14-Membered Tetraazamacrocycles. Dalt. Trans. 2005, No. 18, 3079. (g) Comba, P.; Haaf, C.; Wadepohl, H. Novel Bispidine Ligands and Their First-Row Transition Metal Complexes: Trigonal Bipyramidal and Trigonal Prismatic Geometries. Inorg. Chem. 2009, 48, 6604. (h) Cui, H.-H.; Wang, J.; Chen, X.-T.; Xue, Z.L. Slow Magnetic Relaxation in Five-Coordinate SpinCrossover Cobalt(II) Complexes. Chem. Commun. 2017, 53, 9304.

(32) Arena, G.; Bonomo, R. P.; Musumeci, S.; Purrello, R.; Rizzarelli, E.; Sammartano, S. Thermodynamic and Spectroscopic Properties of Mixed-Ligand Complexes of Copper(II) with Pyridine, 2,2'-Bipyridyl, and 2,2': 6',2"Terpyridyl in Aqueous Solution. J. Chem. Soc., Dalt. Trans. 1983, 1279

(33) Coronado, E.; Gaviña, P.; Ponce, J.; Tatay, S. Fast Pirouetting Motion in a Pyridine Bisamine-Containing Copper-Complexed Rotaxane. Chem. - A Eur. J. 2014, 20, 6939.

(34) Stoll, S.; Schweiger, A. EasySpin, a Comprehensive Software
Package for Spectral Simulation and Analysis in EPR. $J$. Magn. Reson. 2006, 178, 42.

(35) Baumann, F.; Livoreil, A.; Kaim, W.; Sauvage, J.-P. Changeover in a Multimodal Copper(Ii) Catenate as Monitored by EPR Spectroscopy. Chem. Commun. 1997, 35.

(36) This hypothesis is supported by a study from Sauvage and coworkers in which they observed two one-electron reduction events in the $\mathrm{Zn}^{\mathrm{II}}$-complex of a bis-phenanthroline catenane, the reduced states of which were demonstrated by $\mathrm{CV}$ and polarography measurements to be best described as $\mathrm{Zn}^{\mathrm{II}}$ stabilized ligand centered radical anions. ${ }^{13 \mathrm{~d}}$

(37) (a) Mandal, T. N.; Roy, S.; Barik, A. K.; Gupta, S.; Butcher, R. J.; Kar, S. K. Unusual Complexation of $\mathrm{Cu}(\mathrm{I})$ by Pyrimidine/Pyridine-Pyrazole Derived Ligands Exploiting the Molecular Function of 2-Mercapto-4,6Dimethylpyrimidine - Syntheses, Crystal Structures and Electrochemistry. Inorganica Chim. Acta 2009, 362, 1315. (b) Abdolmaleki, S.; Ghadermazi, M. Novel Pyridinedicarboxamide Derivatives and a Polymeric Copper(II) Complex: Synthesis, Structural Characterization, Electrochemical Behavior, Catalytic and Cytotoxic Studies. Inorganica Chim. Acta 2017, 461, 221.

(38) Livoreil, A.; Sauvage, J.-P.; Armaroli, N.; Balzani, V.; Flamigni, L.; Ventura, B. Electrochemically and Photochemically Driven Ring Motions in a Disymmetrical Copper [2]-Catenate. J. Am. Chem. Soc. 1997, 119, 12114.

(39) Collman, J. P.; Yan, Y.-L.; Eberspacher, T.; Xie, X.; Solomon, E. I. Oxygen Binding of Water-Soluble Cobalt Porphyrins in Aqueous Solution. Inorg. Chem. 2005, 44, 9628.

(40) (a) Jurca, T.; Farghal, A.; Lin, P. H.; Korobkov, I.; Murugesu, M.; Richeson, D. S. Single-Molecule Magnet Behavior with a Single Metal Center Enhanced through Peripheral Ligand Modifications. J. Am. Chem. Soc. 2011, 133, 15814. (b) Habib, F.; Luca, O. R.; Vieru, V.; Shiddiq, M.; Korobkov, I.; Gorelsky, S. I.; Takase, M. K.; Chibotaru, L. F.; Hill, S.; Crabtree, R. H.; Murugesu, M. Influence of the Ligand Field on Slow Magnetization Relaxation versus Spin Crossover in Mononuclear Cobalt Complexes. Angew. Chem. Int. Ed. 2013, 52, 11290.

(41) Frost, J. M.; Harriman, K. L. M.; Murugesu, M. The Rise of 3d Single-Ion Magnets in Molecular Magnetism: Towards Materials from Molecules? Chem. Sci. 2016, 7, 2470.

(42) Cotton, F.A., Wilkinson, G., Murillo, C.A., and Bochmann, M. Advanced Inorganic Chemistry. Sixth Edition. John Wiley and Sons, Inc. New York. Wiley-Interscience Publication. John Wiley and Sons, Inc. 1999.

(43) The electrochemical and EPR experiments of $[\mathrm{Co}(6)]\left(\mathrm{ClO}_{4}\right)_{2}$ were carried out in 1,2-dichloroethane as the stability of the complex to repeated redox cycling was found to be increased in this solvent when compared to acetonitrile (Figure S157).

(44) Papadopoulos, C. D.; Hatzidimitriou, A. G.; Voutsas, G. P.; Lalia-Kantouri, M. Synthesis and Characterization of New Addition Compounds of Bis(Substituted-Salicylaldehydo) Cobalt(II) with 2,2'-Bipyridine (Bipy). Crystal and Molecular Structures of [Co(II)(3-MethoxySalicylaldehyde)2(Bipy)]. $\mathrm{CH}_{3} \mathrm{OH}$ (1) and [Co(II)(Bipy)3]Br2·0.5(5-Chloro-S. Polyhedron 2007, 26, 1077.

(45) Symes, M. D.; Wilson, C. Probing the Effects of Steric Bulk on the Solution-Phase Behaviour and Redox Chemistry of Cobalt-Diimine Complexes. Supramol. Chem. 2018, 30, 742.

(46) Masood, A.; Hodgson, D. J.; Zacharias, P. S. Nickel(II) and Manganese(II) Complexes of Substituted Phenanthroline Ligands. Inorganica Chim. Acta 1994, 221, 99. 